\title{
PUBLIC INJURY AND THE PUBLIC INTEREST: SECONDARY MEANING IN THE LAW OF UNEAIR COMPETITION *
}

\section{Richard H. Stern † AND Jofi E. Hofrman $\ddagger$}

The continued doubts of courts as to the proper function of the private damages or injunction suit in trade regulation law are reflected as much in the interstices of analysis as in overt doctrinal content. The policy question is usually put, when articulated at all in terms of doctrine, as whether "public injury" is an essential ingredient of the cause of action. According to the proponents of the "public injury" doctrine, to be heard in court the private litigant must bring a suit which will vindicate the public interest, and not merely redress his private griefs. In this view, the relief given the plaintiff is deemed but incidental to the main purpose of redressing injuries to the competitive process, ${ }^{1}$ or to the public at large, in whose behalf the plaintiff functions as a "private attorney general." 2 With those who do not accept the "public injury" rationale of trade regulation law, however, the focus of inquiry is placed on the balance of plaintiff's and defendant's interests, without specific reference to the more general economic impact of the dispute. ${ }^{3}$

* Grateful acknowledgment is made to Professor Friedrich Kessler of the Yale Law School for his many helpful comments.

The views expressed are those of the authors and do not necessarily reflect those of the Government. Some of the material in the present article appeared in a different form in 32 CoNN. B.J. 381 (1958).

$\dagger$ A.B. 1953, B.S.E.E. 1954, Columbia University; LL.B. 1959, Yale University. Member, Connecticut Bar. Law clerk to Associate Justice Byron R. White of the United States Supreme Court.

\$B.A. 1957, New York University; LL.B. 1960, Yale University. Member, New York Bar. Trial Attorney, U.S. Dep't of Justice.

1 The basis of liability thus resembles that of the common-law public nuisance action, which must be rested upon the infringement of interests both common to the general public and peculiar to the plaintiff. See Pennsylvania Coal Co. v. Mahon, 260 U.S. 393, 413 (1922); The King v. Lloyd, 4 Esp. 200, 170 Eng. Rep. 691 (K.B. 1802).

2 See Maltz v. Sax, 134 F.2d 2, 4 (7th Cir.) (dictum), cert. denied, 319 U.S. 772 (1943); Comment, 49 YaLE L.J. 284, 296 (1939).

3 Compare Loevinger, Private Action-The Strongest Pillar of Antitrust, 3 ANTITRust Bull. 167, 175 (1958) (private injury sufficient, proof of public injury unnecessary), zeit/ American Washboard Co. v. Saginaw Mfg. Co., 103 Fed. 281, 284-85 (6th Cir. 1900) (private injury must be shown, public injury insufficient). 
Although most familiar in the antitrust context," the "public injury" controversy, under the name "secondary meaning," permeates unfair competition and trademark law as well. " The term "unfair competition" has been applied to many different business torts, among them trade libel, malicious interference with contractual relations, commercial bribery, espionage, and predatory price-cutting. ${ }^{6}$ The phrase "unfair methods of competition," as used in section 5(a) of the Federal Trade Commission Act, ${ }^{7}$ has an even broader scope. ${ }^{8}$ This Article does not deal, however, with "public injury" in connection with these regrettable lapses of business ethics. Its scope is restricted to that older sense of "unfair competition" which is closely akin to trademark

4 Scarcely a term of the Supreme Court passes now without an antitrust "public injury" case. See, e.g., Radiant Burners, Inc. v. Peoples Gas Light \& Coke Co., 364 U.S. 656 (1961) ; Klor's, Inc. v. Broadway-Hale Stores, Inc., 359 U.S. 207 (1959); Radovich v. National Football League, 352 U.S. 445 (1957). Among the more significant court of appeals opinions are Packard Motor Car Co. v. Webster Motor Car Co., 243 F.2d 418 (D.C. Cir.), cert. denied, 355 U.S. 822 (1957); Ruddy Brook Clothes, Inc. v. British \& Foreign Marine Ins. Co., 195 F.2d 86 (7th Cir.), cert. denied, 344 U.S. 816 (1952) ; Feddersen Motors, Inc. v. Ward, 180 F.2d 519 (10th Cir. 1950). The Supreme Court cases have uniformly held that public injury is not an additional element of the cause of action, to be proved along with a substantive violation and consequent private injury. This does not mean, of course, that an actual or probable impairment of the vigor of competition may not have to be shown, in a non-per se case, in order to make out the substantive violation. In a more sophisticated sense then, "public injury" may be identified with injury to competition ("unreasonable restraint of trade," "substantial lessening of competition"), as distinguished from mere injury to competitors. As used in this article "public injury" will not refer to matters of pleading; it will be applied only in connection with the question of whether impact on the public is necessary to make out a substantive violation.

5 See also $\$ 5$ (b) of the Federal Trade Commission Act, 38 Stat. 719 (1914), as amended, 15 U.S.C. $\$ 45$ (b) (1958), which requires as a condition to the filing of a complaint that it "appear to the Commission" that a proceeding would be to the public interest. FTC v. Klesner, 280 U.S. 19, 28 (1929); Klor's, Inc. v. Broadway-Hale Stores, Inc., 359 U.S. 207, 211 n.4 (1959) (dictum). There is, of course, no private damages action under $\$ 5$. Kessler \& Stern, Competition, Contract, and Vertical Integration, 69 YALE L.J. 1, 64 n.282 (1959) (collecting authorities).

Under patent or copyright law, where there is a statutory monopoly for a limited period, no public injury need be shown to authorize a suit against an infringer, but the "misuse" doctrine bars enforcement of the monopoly when it is being used in contravention of the public interest, or in derogation of the common right. See Morton Salt Co. v. G. S. Suppiger Co., 314 U.S. 488 (1942) ; Motion Picture Patents Co. v. Universal Film Mfg. Co., 243 U.S. 502 (1917).

In related regulatory fields, see Scripps-Howard Radio, Inc. v. FCC, 316 U.S. 4, 14-15 (1942) ("[P] rivate litigants have standing only as representatives of the public interest. . . [T] [Te rights to be vindicated are those of the public and not of the private litigants.") ; Reade v. Ewing, 205 F.2d 630, 632 (2d Cir. 1953) (Food, Drug and Cosmetic Act); Associated Indus., Inc. v. Ickes, 134 F.2d 694, 704 (2d Cir.), vacated as moot, 320 U.S. 707 (1943) (Bituminous Coal Act); Seatrain Lines, Inc. v. United States, 152 F. Supp. 619, 625 (D. Del), aff'd per curian, 355 U.S. 181 (1957) (Interstate Commerce Act); FCC v. National Broadcasting Co. (KOA), 319 U.S. 239, 259-60 (1943) (dissenting opinion of Frankfurter, J.).

- See Handler, Unfair Competition, 21 Iowa L. Rev. 175 (1936).

738 Stat. 719 (1914), as amended, 15 U.S.C. \$45(a) (1958).

8 See FTC v. Bunte Bros., 312 U.S. 349, 354 (1941). 
infringement: the tort which the first entrant to a market alleges when a competitor enters the same arena seeking to sell similar goods. ${ }^{9}$

Under the "public injury" rule, as it is applied to unfair competition law, the first entrant is allowed to protect his market position by an unfair competition action only if the public has been injured in that it was deceived by the newcomer as to the source of his goodsthat is, the newcomer has misled the public into buying his goods by palming them off as those of his rival. Absent public injury in the form of "palming off," however, the first entrant would be denied a cause of action against the newcomer. Thus, in the traditional view, as enunciated by its most persuasive spokesman, the late Judge Learned Hand:

[I]t is an absolute condition to any relief whatever that the plaintiff . . . show that the appearance of his wares has in fact come to mean that some particular person-the plaintiff may not be individually known-makes them, and that the public cares who does make them, and not merely for their appearance and structure. . . . The critical question of fact at the outset always is whether the public is moved in any degree to buy the article because of its source ... . ${ }^{10}$

Others, however, believe that the law should protect the innovator against any loss of trade to an imitator seeking a "free ride" on the coattails of his rival, and that it should do so without regard to the presence or absence of public deception. Thus, one leading commentator asserts that "whether the public is actually deceived, or whether the public cares anything about the source . . . is of no importance." 11 This Article attempts to explore the public interest consequences of adopting the one or the other of these conflicting rationales for unfair competition law.

"Secondary meaning," in trademark-unfair competition parlance, is that inference of source to which Judge Hand referred, which a purchaser draws from the appearance or other identifying character-

9 Nor does the scope of this article include cases involving a newcomer's attempts to utilize the actual physical marketing or distribution equipment of another. E.g., Hartford Charga-Plate Associates, Inc. v. Youth Centre-Cinderella Stores, Inc., 215 F.2d 668 (2d Cir. 1954); Meyer v. Hurwitz, 5 F.2d 370 (E.D. Pa. 1925), appeal dismissed per curiam, 10 F.2d 1019 (3d Cir. 1926); Prest-O-Lite Co. v. Davis, 209 Fed. 917, 923 (S.D. Ohio 1913), aff'd per curian, 215 Fed. 349 (6th Cir. 1914); Sperry \& Hutchinson Co. v. Louis Weber \& Co., 161 Fed. 219 (C.C.N.D. I11. 1908). Compare Prest-O-Lite Co. v. Auto Acetylene Light Co., 191 Fed. 90 (C.C.N.D. Ohio 1910) (common law), appeal dismissed per curiam, 191 Fed. 1005 (6th Cir. 1911); Insto-Gas Corp., 54 F.T.C. 741 (1957) (Clayton Act §3). This Article deals only with copying or imitation.

10 Crescent Tool Co. v. Kilborn \& Bishop Co., 247 Fed. 299, 300 (2d Cir. 1917). 1950).

113 Callman, Unfair Competition and Trademarks $\$ 80.6$, at 1371 (2d ed. 
istics of the product and which may be a principal factor in motivating the purchase. The term "secondary meaning" began as a trademarklaw concept applied to descriptive words, particularly geographical ones, which had come to be associated with the product of some particular manufacturer. These words thus acquired a secondary meaning, in addition to their primary, descriptive meaning. In the case of "Glenfield Starch," for example, "Glenfield's" primary connotation of the town of Glenfield was supplemented, or perhaps for many even superseded, by the secondary meaning of one Wotherspoon's mill as a source of starch..$^{12}$ As it is now employed, largely because of the adoption of this usage in Judge Hand's powerful opinions in the leading cases, ${ }^{13}$ the term is applied to the physical appearance of the goods as well as the name. Stated in terms of art, then, the dispute over the proper function of the private unfair competition action ${ }^{14}$ is the dispute over whether the existence of "secondary meaning" is an indispensable condition to maintenance of the first entrant's suit.

Assume that a manufacturer intentionally copies a novel element of an innovating manufacturer's name, packaging, or product. The copied element may (1) help fulfill the purpose to be served by the product in the hands of the consumer, ${ }^{15}$ (2) indicate to the purchaser the nature of the product, ${ }^{16}$ or (3) indicate the source of the product. ${ }^{17}$ If the copied feature has the first-named quality, it is deemed to be

12 Wotherspoon v. Currie, L.R. 5 H.L. 508 (1872); see Reddaway v. Banham, [1896] A.C. 199 ("camel hair belting"). To be sure, as Judge Hand pointed out in the passage quoted in text accompanying note 10 supra, the maker need not be individually known by name, and a notion of some single, though anonymous, source will suffice for purposes of secondary meaning. See Shredded Wheat Co. v. Humphrey Cornell Co., 250 Fed. 960, 963 (2d Cir. 1918); Saalfield Publishing Co. v. G. \& C. Merriam Co., 238 Fed. 1, 8-9 (6th Cir.), cert. desiied, 243 U.S. 651 (1917).

The use of "secondary" to designate the meaning of the words which has, in fact, come to be their usual and primary significance in the market has aptly been termed "a triumph of unintended obfuscation." KAPLAN \& BROWN, CASES ON Copyright, Unfarr Competition, AND OTher Topics 490 (1960). But this term of art is by now thoroughly entrenched in the case law, and the writers will use it in its conventional sense throughout this article, rather than attempt to coin a more felicitous phrase. See Restatement, ToRTs $\$ 716$, comment $b$ (1938).

13 These cases are discussed in text accompanying notes 74-90 infra.

14 This is, in fact, the dispute over the role of unfair competition law itself, for, unlike the antitrust laws or the Federal Trade Commission Act, the law of unfair competition with which we are concerned is applied solely in private litigation.

15 E.g., the shape of a set of dishes or the design printed on them may help fulfill the aesthetic or utilitarian purpose for which the consumer buys them. See Pagliero v. Wallace China Co., 198 F.2d 339 (9th Cir. 1952).

16 E.g., "Rhine wine" on the label indicates to prospective purchasers the particular type of wine in the bottle. See Restatement, Torts $\$ 720$, comment $c$ (1938).

17 E.g., the shape of the Haig \& Haig "pinch bottle" indicates to some shoppers the source of its contents without the need of a label. See Ex parte Haig \& Haig, Ltd., 118 U.S.P.Q. 229 (Comm'r of Patents 1958). 
"functional." 18 The second quality is termed "descriptiveness." 19 The third quality, "source-indicativeness," as we have seen, is closely identified with "secondary meaning." 20 These terms designate the three principal operative facts on which courts have focused their attention in adjusting the competing claims of innovators, copyists, and the public under the "public injury" doctrine.

The "misappropriation" doctrine operates independently of functionality, descriptiveness, and, above all, secondary meaning. Focussing exclusively on the question of the innovator's "property rights" in the copied feature, ${ }^{21}$ this approach emphasizes the moral quality of

18 "Functionality" has been restricted by some to those minimal features without which an object would not be considered to be a member of its class. Thus, in Haeger Potteries, Inc. v. Gilner Potteries, Inc., 123 F. Supp. 261, 271 (S.D. Cal. 1954), the court proscribed copying of the ornamental aspects of an ashtray, because "holding ashes is its function ... ." In Pagliero v. Wallace China Co., 198 F.2d 339 (9th Cir. 1952), however, copying designs on dishes was permitted, since the design was recognized to be an "essential selling feature" of the product. Id. at 343 . The court said that "china satisfies a demand for the aesthetic as well as for the utilitarian ... [T] he design is, at least in part, the response to such demand ..." Id. at 344 .

The Pagliero case represents the more common view. See, e.g., Vaughan Novelty Mfg. Co. v. G. G. Greene Mfg. Corp., 202 F.2d 172, 175-76 (3d Cir.), cert. denied, 346 U.S. 820 (1953) ; J. C. Penney Co. v. H. D. Lee Mercantile Co., 120 F.2d 949, 954 (8th Cir. 1941). This view is set out in Restatement, ToRTs \$ 742 \& comment $a$ (1938) (feature is nonfunctional only if, when omitted, nothing of substantial value in the goods is lost).

10 See generally Restatement, Torts $\$ 721$ (1938) (descriptive of ingredients, quality, properties, functions). As the term will be used here, it will not be restricted to words or arbitrary symbols, i.e., conventional trademarks. Instead, it will be applied to more general product configurations as well. Packaging, for example, frequently appears to be descriptive, in that certain arbitrary configurations become generic for classes of product. In Lucien Lelong, Inc. v. Lander Co., 164 F.2d 395 (2d Cir. 1947), a certain bottle shape appears to have acquired the special significance that the contents were cologne. Compare the very similar bottle shapes used for the various brands of liquid heavy-duty household cleaning agents. Arbitrary colors may also become associated with products and identify them-brown for cola-flavored drinks, see Coca-Cola Co. v. Dixi-Cola Labs., Inc., 155 F.2d 59, 65-66 (4th Cir.), cert. denied, 329 U.S. 773 (1946); pink for soothing stomachics, see Norwich Pharmacal Co. v. Sterling Drug, Inc., 271 F.2d 569, 572 (2d Cir. 1959), cert. denied, 362 U.S. 919 (1960); yellow-green for the liquid detergents referred to stpra.

20 Secondary meaning requires (1) source-indicativeness of the feature, an association created in the minds of the consumer between configuration of the goods, or the name applied to them, and some single, although perhaps anonymous, source, plins (2) the consumers' caring sufficiently about whose goods they buy to be induced by the presence of the feature to purchase goods with that configuration or label. This is the test of Crescent Tool, quoted in text at note 10 supra. To the same effect, see, e.g., Blisscraft of Hollywood v. United Plastics Co., 294 F.2d 694, 697 (2d Cir. 1961); Lucien Lelong, Inc. v. Lander Co., 164 F.2d 395, 397 (2d Cir. 1947) ; Sinko v. Snow-Craggs Corp., 105 F.2d 450, 453 (7th Cir. 1942); W. E. Bassett Co. v. H. C. Cook Co., 164 F. Supp. 278, 283 (D. Conn. 1958). See also discussion in notes 74-90 infra and accompanying text.

21 But see Callmann, He Who Reaps Where He Has Not Sozon, 55 Harv. I. Rev. 595, 597 n.9 (1942) (characterizing the interest as "relational," rather than "property"); Sell, The Doctrine of Misappropriation in Unfair Competition, 11 VAND. L. REV. 483, 498 (1958). The pragmatic difference between the two formulations is unclear, however, with respect to overcoming the serious difficulties in application of the doctrine discussed in notes 147-56 infra and accompanying text. Cf. Callmann, supra at 597. 
the copyist's conduct, and the only public interest ${ }^{22}$ with which it is directly concerned is the public interest in maintaining ethical standards of commercial behavior. ${ }^{23}$ "Misappropriation" is the only remaining important term of art used in the discussion, and it is employed exclusively by those who oppose the public injury doctrine. Followers of traditional doctrine, such as Judge Hand, do not deem misappropriation an operative concept in deciding unfair competition cases; the opposing school, as we have noted, returns the compliment by disregarding "secondary meaning and all that."

The principal impetus for the misappropriation doctrine has been the celebrated Supreme Court decision in International Nerws Serv. v. Associated Press. ${ }^{24}$ INS had pirated AP news reports and sold them as its own product. The Supreme Court, over a vigorous Brandeis dissent, found unfair competition: "It is said that the elements of unfair competition are lacking because there is no attempt by defendant to palm off its goods as those of the complainant . . . . But we cannot concede that the right to equitable relief is confined to that class of cases. . . ." 25 A case for relief from unfair competition

22 We submit that it begs the "public injury" question to regard the innovator's claims by themselves as involing the public interest in the same sense as do the consumer's claims to the material benefits of competition. In this sense of "public injury," any private harm injures the public, and all injury is public injury. But the whole thrust of the "public injury" doctrine is to the contrary. Cf. FTC v. Klesner, 280 U.S. 19, 28 (1929), in which the Court stated that "the mere fact that it is to the interest of the community that private rights shall be respected is not enough to support a finding of 'public interest'." Commenting on this case, Callman regretfully observes that "the courts have seemingly devoted themselves to the protection of the more materialistic interests of the general public," rather than the "idealistic interest" in "observing the rules of the game." 1 Callman, UNFarr CoMperition aND TRadeMARKS \$ 3.4, at 55-56 (2d ed. 1950). Is not the maximization of the materialistic interests of the general public (the greatest goods for the greatest number) the "rule of the game" in our social order? See Northern Pac. Ry. v. United States, 356 U.S. 1,4 (1958).

${ }^{23}$ See Callmann, supra note 21, at 599. The outlawing of misappropriation might also be defended as consistent with the policies of free competition, despite its primary concern with standards of conduct, on the ground that it stimulates innovation. The foreclosure of copying is said to force businessmen to "innovate around" their rivals' products and thus benefit the public by producing a greater diversity of innovations directed to the same end. See James P. Marsh Corp. v. United States Gauge Co., 129 F.2d 161, 165 (7th Cir. 1942) ; Stedman, Invention and Public Policy, 12 LAW \& Contremp. ProB. 649, 653 (1947); cf. Frost, The Patent System and the Modern Economy, S. Doc. No. 22, 85th Cong., 1st Sess. 6 (1957). But cf. Triangle Publications, Inc. v. Rohrlich, 167 F.2d 969, 980 n.13 (2d Cir. 1948) (querying "reward to innovator" theory of unfair competition); Standard Brands, Inc. v. Smidler, 151 F.2d 34, 41 n.12 (2d Cir. 1945) (same); Stedman, sutpra at 662 (same in patent context). It is questionable whether, with regard to any specific product, this type of competition is a satisfactory substitute for the "hard competition" in marketing which is reflected by lower prices to the public. More generally, with regard to the economy as a whole, channeling research and development facilities into different methods for achieving particular ends is hardly the most desirable allocation of limited resources. See Staff of Subcomm. on Patents, Trademarks, and Copyrights, Senate Comm. on the Judiciary, 85th Cong., 2d Sess., An Economic Review of the Patent System 50-52 (Comm. Print 1958).

24248 U.S. 215 (1918).

$25 I d$. at $241-42$. 
exists, said the Court, when there is misappropriation of the product of plaintiff's "labor, skill and money," when "defendant in appropriating it [news] and selling it as its own is endeavoring to reap where it has not sown . . appropriating to itself the harvest of those who have sown. . . . in order to divert . . . profit from those who have earned it to those who have not . . . ."26

The case was ignored for many years, and courts declined to follow its suggestion that unfair competition doctrine be expanded to protect this interest. ${ }^{27}$ Indeed, Judge Wyzanski once stated his belief that a majority of the Supreme Court would now follow the Brandeis dissent and overrule INS if given the opportunity. ${ }^{28}$ The New York courts, however, starting with cases involving the misappropriation of news and artistic productions, ${ }^{29}$ retrieved INS from its innocuous desuetude and gradually extended the doctrine into the area of unfair competition in the sale of goods. ${ }^{30}$ The INS doctrine was codified into positive law by New York in 1955..$^{31}$ Several other states have adopted similar legislation, ${ }^{32}$ and a bill has been introduced into Congress to make it the federal law..$^{33}$

\section{Failure to Recognize the Policies at Stake}

Courts rarely articulate precisely, if they recognize at all, the choice they make in unfair competition cases between the two com-

26 Id. at $239-40$.

27 See, e.g., G. Ricordi \& Co. v. Haendler, 194 F.2d 914 (2d Cir. 1952) ; National Comics Publications, Inc. v. Fawcett Publications, Inc., 191 F.2d 594 (2d Cir. 1951); RCA Mfg. Co. v. Whiteman, 114 F.2d 86 (2d Cir.), cert. denied, 311 U.S. 712 (1940); Cheney Bros. v. Doris Silk Corp., 35 F.2d 279 (2d Cir. 1929), cert. denied, 281 U.S. 728 (1930). Since Erie R.R. v. Tompkins, 304 U.S. 64 (1938), INS has had, of course, little precedential weight. Cf. Maternally Yours, Inc. v. Your Maternity Shop, Inc., 234 F.2d 538, 540-41 (2d Cir. 1956).

28 Triangle Publications, Inc. v. New England Newspaper Publishing Co., 46 F. Supp. 198, 204 (D. Mass. 1942).

20 See Metropolitan Opera Ass'n v. Wagner-Nichols Recorder Corp., 279 App. Div. 632, 107 N.Y.S.2d 795 (1951) (commercial recording of opera broadcast); Madison Square Garden Corp. v. Universal Pictures Co., 255 App. Div. 459, 7 N.Y. S.2d 845 (1938) (newsreel photos purporting to be of "Rangers" in Garden, but actually of "Rangers" on road) ; Rudolph Mayer Pictures, Inc. v. Pathe News, Inc., 235 App. Div. 774, 255 N.Y. Supp. 1016 (1932) (memorandum decision) (pirated motion pictures of Sharkey-Walker fight); Mutual Broadcasting System, Inc. v. Muzak, 177 Misc. 489, 30 N.Y.S.2d 419 (Sup. Ct. 1941) (rebroadcast of World Series).

30 The New York cases, in federal and state courts, are reviewed in KAPLAN \& Brown, op. cit. supra note 12, at 508-09, 597-611; Stern, Buyer Indifference and Secondary Meaning in Unfair Competition and Trademark Cases, 32 CoNs. B.J. 381, 387-88, 391-92 (1958) ; Comment, 70 YALE L.J. 406, 418-21, 426-30 (1961).

31 N.Y. GEN. Bus. LAW \$ 368-d.

32 See, e.g., GA. Cone ANn. §106-115 (1956); Ill. Ann. Stat. ch. 140, §22 (Smith-Hurd Supp. 1961) ; MASs. ANN. LAws ch. 110, §7A (1954) (substantially same wording as New York statute).

33 H.R. 4590, 87th Cong., 1st Sess. (1961). There had been some who believed that Congress had already enacted a federal law of unfair competition in the Lanham Act $\$ \$ 43$ (a), 44(h)-(i), 60 Stat. 441, 443 (1946), 15 U.S.C. $\$ \S 1125$ (a), 1126(h) -(i) (1958), but the preponderance of the cases are now to the contrary. See authorities collected in Kessler \& Stern, supra note 5, at 100 n.455. 
peting rationales and their underlying policies. Instead, the decisions are often shrouded in unhelpful conclusions phrased in the legal mysticism of "secondary meaning" on the one hand or of "property rights" on the other. ${ }^{34}$ The two decisions discussed below reveal the too common judicial failure to recognize the operative facts in the case and illustrate the inadequacy of much of the legal analysis in this area. Most important, they illustrate the unsatisfactory results to which such faulty analysis may lead.

\section{A. The Notre Dame Case}

The Notre Dame case, John Roberts Mfg. Co. v. University of Notre Dame $d u L a c,{ }^{35}$ involved the distribution of class rings by an unlicensed manufacturer in competition with the "official" product sponsored by the university. The rings, exact duplicates of one another, embodied the university seal and monogram, as well as the name "University of Notre Dame." In his merchandising, the copyist prominently featured the name of his firm as the manufacturer of the ring he sold, and he placed his own trademark on the ring itself. ${ }^{36}$ Neither the district court nor the court of appeals deemed this relevant, however, for as the district court put it, "no one is so naive as to think for one moment that a student . . . is going to ascertain who makes the ring before he buys it." 37 What was deemed the crucial fact was that in making his rings the copyist used the Notre Dame name, seal, and monogram without the university's consent, an appropriation of property rights which the court equated to the purloining of cash from the university's safe deposit box. ${ }^{38}$

The copyist sought to defend his use of the university's name, in his advertising and on the product itself, on the ground that "Notre Dame" was descriptive in that context. But the court of appeals tersely declared that this claim "borders on the preposterous." ${ }^{39}$ The argu-

34 See Cohen, Transcendental Nonsense and the Functional Approach, 35 CoLuns. L. REv. 809, 814-17 (1935) ; cf. United States v. Willow River Power Co., 324 U.S. $499,502-03$ (1945).

35258 F.2d 256 (7th Cir. 1958), affirming 152 F. Supp. 269 (N.D. Ind. 1957).

36152 F. Supp. at 271.

37 Id. at $271-72$.

38258 F.2d at 259, 262. For a similar example of purloining, see Vassar College v. Loose-Wiles Biscuit Co., 197 Fed. 982 (W.D. Mo. 1912), where the loose wiles of the copyist included appropriation of the college name and seal, with "Vassar College" and "Purity and Wisdom" on the seal replaced by "Vassar Chocolates" and "Always Fresh." The court however, found no legally cognizable injury. Compare Yale Univ. v. Benneson, 147 Conn. 254, 159 A.2d 169 (1960), with Cornell Univ. v. Messing Bakeries, Inc., 285 App. Div. 490, 138 N.Y.S.2d 280 (1955).

39258 F.2d at 261. 
ment, however, deserves less cavalier treatment; a Notre Dame class ring can hardly be called anything else. ${ }^{40}$ Perhaps, the value to the public of such descriptiveness is outweighed by other considerations. But determination of this issue is more hampered than furthered by denial that use of the name involves descriptiveness at all.

Furthermore, although functionality was discussed by neither trial nor appellate court, the university name, seal, and monogram are clearly functional when used in connection with this product. Without these features, the ring would be something else, perhaps desirable for other purposes, but not as a Notre Dame class ring. And to whatever extent esthetic appeal is a factor in the sale of these rings, further functionality is involved. Neither court purported to protect the design of the ring qua design ${ }^{41}$ or qua quasi-diploma. ${ }^{42}$ The thrust of both opinions goes to the unauthorized use of the symbols in the ring, which are deemed the incorporeal property of the university. To be sure, the use of these symbols might justifiably be prevented, under conventional doctrine, had the elements been used to cast an aura of University sponsorship over the product."3 But since such "palming off" was assumed away here, ${ }^{44}$ the court was eliminating competition in the sale of the ring in the name only of protecting the separate elements of the unprotected (or unprotectable) whole. ${ }^{45}$ As is the case

${ }^{40}$ Compare Saalfield Publishing Co. v. G. \& C. Merriam Co., 238 Fed. 1, 7 (6th Cir.), cert. denied, 243 U.S. 651 (1917), where the court held that a dictionary based on the original Noal Webster dictionary (already in the public domain by then) could hardly be called anything but a "Webster"; Gotham Music Serv., Inc. v. Denton \& Haskins Music Publishing Co., 259 N.Y.' 86, 89, 181 N.E. 57, 58 (1932), where the court held that there was no practical way to designate the song "St. James Infirmary" but by its name; REsTATEMENT, TORTS $\$ 721$, comment $a$ (1938) ("Plow" cannot be a trademark for plows).

41 Compare Cheney Bros. v. Doris Silk Corp., 35 F.2d 279 (2d Cir. 1929), cert. denied, 281 U.S. 728 (1930), with Flint v. Oleet Jewelry Mfg. Co., 133 F. Supp. 459 (S.D.N.Y. 1955), discussed in text at notes 91-92 infra.

42 The university's interest in protecting itself against forgery of its diplomas, which it issues pursuant to state regulations, is unquestionable. The real danger to the university of having its reputation cast into the hands of strangers, see Yale Elec. Corp. v. Robertson, 26 F.2d 972, 974 (2d Cir. 1928), warrants its possession of power to determine who will possess Notre Dame diplomas. We question, however, whether these considerations apply to selling class rings, for little but a commercial venture appears to be involved. The university did not attempt to place any equitable servitude on the chattels, cf. Dr. Miles Medical Co. v. John D. Park \& Sons Co., 220 U.S. 373 (1911), and it specifically contemplated use of the university emblems (in a special version of the ring) by "feminine friends and feminine members of the families of qualified wearers of the official Notre Dame ring." 152 F. Supp. at 273.

43 See, e.g., Triangle Publications, Inc. v. Rohrlich, 167 F.2d 969 (2d Cir. 1948); Yale Elec. Corp. v. Robertson, 26 F.2d 972 (2d Cir. 1928) (leading case) ; Standard Brands, Inc. v. Smidler, 151 F.2d 34, $42-43$ (2d Cir. 1945) (concurring opinion) (explaining rule).

44 See text accompanying note 37 supra.

45 Compare Restatement, Torts $\$ 724$ (1938) (protected whole may be made up of unprotected elements). We believe that the design of the ring should not be protected in the name of protection of the elements, when the kind of protection the elements are properly to be conceded is trademark-trade name protection (see id. $\$ 730$ ), whereas the only kind of protection at stake for the whole is protection from 
with descriptiveness, it is arguable that the public interest in unmonopolized functionality is subordinate to other values; but the courts owe the parties and the public, which ultimately feels the market impact of unfair competition decisions, a more explicit balancing, or at least recognition, of competing policies than can be discerned here. ${ }^{46}$ Such a balancing is particularly necessary when as in the Notre Dame case ${ }^{47}$ the purchasers of the product are indifferent to its source, since the absence of any countervailing public interest in preventing the copying makes the policy favoring competition, which is usually deemed socially useful, especially significant.

\section{B. The Atmos Clock Case}

A conceptually more complex situation was involved in the Atmos Clock case, Mastercrafters Clock \& Radio Co. v. Vacheron \& Constantin-Le Coultre Watches, Inc., ${ }^{48}$ the opinion in which was written by the late Judge Jerome Frank. The innovator Vacheron distributed the distinctive "Atmos" clock, operated solely by a mechanism sensitive to atmospheric temperature and pressure changes. Although distinctive, the Atmos was neither patented nor copyrighted. ${ }^{49}$ The copyist Mastercrafters manufactured the " 308 " clock, which closely resembled the Atmos in external appearance, but which relied on a relatively inexpensive electric motor within the clock for power. While the Atmos retailed at $\$ 175$, the 308 sold for $\$ 40$. The district court found as a fact that buyers of the 308 were not deceived into thinking they were buying an Atmos, for Mastercrafters' name was on the dial and an electric cord hanging from the back of the case was plainly visible. ${ }^{50}$ The buyers knew what they were doing; they paid $\$ 40$ for a "luxury design," "prestigious" clock which their guests would imagine had cost them $\$ 175$ (provided the cord was kept out of sight). Clearly, the only people who could be deceived would be the guests. Hence the district court allowed neither damages nor an injunction to the innovator..$^{51}$

product design copying. The use of the elements in the Notre Dame case was not "trademark use," cf. American-Marietta Co. v. Krigsman, 275 F.2d 287 (2d Cir. 1960); Hansen v. Siegel-Cooper Co., 106 Fed. 691 (C.C.S.D.N.Y. 1900), although trademark protection was what was granted.

${ }^{46}$ See Kessler, Arthur Linton Corbin-A Tribute, 64 Yale L.J. 161, 166 (1954). 47 See text accompanying note 37 supra.

48221 F.2d 464 (2d Cir.), cert. denied, 350 U.S. 832 (1955), reversing 119 F. Supp. 209 (S.D.N.Y. 1954).

49 Compare Vacheron \& Constantin-Le Coultre Watches, Inc. v. Benrus Watch Co., 155 F. Supp. 932 (S.D.N.Y. 1957), modified, 260 F.2d 637 (2d Cir. 1958).

50119 F. Supp. at 211-12.

$51 \mathrm{Id}$. at 213-16. See also 110 F. Supp. 694 (S.D.N.Y. 1953) (denying temporary injunction). 
The court of appeals reversed, holding that the likelihood of confusion of visitors to 308-buyers' homes, who would fail to observe the well-concealed electrical cord and therefore assume that the clock was an Atmos, sufficed to render the copyist's conduct actionable. Judge Frank's opinion raises perplexing doctrinal problems (some of which ${ }^{52}$ are far beyond the scope of this Article).

The interest which the court of appeals purports to protect is that of the public qua the buyer's guest who may be misled into believing that his host can afford the $\$ 175$ Atmos. In order to provide such protection, the court developed, sub silentio, a doctrine of contributory unfair competition analogous to contributory infringement in patent law..$^{53}$ The court conceded that whatever unfair practices were involved did not prejudice the actual buyers of the clock, who received fair warning, and the court's determination of impermissible conduct was based solely on the copyist's contribution to the host's tasteless behavior.

Even if one accepts the premise that there is a public interest in frustrating this sort of social climbing, ${ }^{54}$ it does not necessarily follow that the interest should be vindicated by the award of an injunction or damages against the copyist. The coordinate public interest in easy access to the desirable features of the Atmos design deserves, at least, to be weighed in determining the issue. An analysis which purports to revolve about protection of the public should take into account the public interest in keeping the esthetic functionality of the design, which was unprotected by design patent or copyright, effectively in the public domain; recognition of the possibility of source-confusion should be the beginning, not the end, of analysis.

Although the court did not choose to articulate it, it would nevertheless appear that the real basis of the decision, and the only one at all tenable, is that Mastercrafters "misappropriated" the Atmos de-

52 See text preceding note 58 infra (general theory of contributory unfair competition).

53 See Zangerle \& Peterson Co. v. Venice Furniture Novelty Mfg. Co., 133 F.2d 266, 269 (7th Cir. 1943) ; cf. William R. Warner \& Co. v. Eli Lilly \& Co, 265 U.S. 526, 529-31 (1924); Hiram Walker \& Sons v. Corning \& Co., 255 Fed. 129, 131 (N.D. Ill. 1918); REstatearent, ToRTs $\$ \S 738-39$ (1938) (trademarks and trade names). Compare the district court's opinion in the Notre Dame case, where an asserted part of the copyist's wrong was that he gave sophomores, nonalumni, and other "unqualified persons" (e.g., women not the "feminine members of the families of the qualified wearers of the official Notre Dame ring," 152 F. Supp. at 273) a means to misrepresent themselves to the public as to their scholastic (or other) accomplishments. Id. at 275 .

54 But cf. Standard Brands, Inc. v. Smidler, 151 F.2d 34, 41 n.13 (2d Cir. 1945) (Frank, J., concurring). In our view, the law of unfair competition exists to protect the public only qua buyer or direct consumer. See K. Taylor Distilling Co. v. Food Center, Inc., 31 F. Supp. 460, 462 (E.D. Mo. 1940) (dictum). See also note 138 infra. 
sign. $^{55}$ There is some indication in the opinion that the court recognized this. In discussing the question of burden of proof, the statement is made that the copyist's "intention thus to reap financial benefits from poaching on the reputation of the Atmos clock is of major importance." ${ }^{56}$ Whether a judge with the strong views on competition that Jerome Frank had could have brought himself to articulate a "misappropriation" decision is, however, most doubtful to these writers. ${ }^{57}$ But in that case, he had no business reaching the result he reached. The moral, if any is appropriate, is that even a great judge can mishandle unfair competition problems by inadequate characterization of the policy issues.

A further difficulty in the Atmos Clock analysis, but one unrelated to secondary meaning, lies in its treatment of contributory infringement. Without attempting to formulate a general theory of contributory unfair competition, a task which would carry us far afield from "public injury," we suggest that on facts such as these the innovating manufacturer should have no cause of action against the copyist-the alleged contributory unfair competitor-even assuming that deceiving one's guests is unfair competition. It is axiomatic that if the buyer cannot be amerced as a direct tortfeasor, the one who sells to him cannot be amerced for contributing to a nonexistent tort. ${ }^{58}$ It would appear, however, that there is no likelihood of pecuniary injury to the maker or seller of Atmos by reason of the "direct" unfair competition by the guest-deceiving, 308-buying host. ${ }^{58}$ Loss of the sales

55 See Zippo Mfg. Co. v. Manners Jewelers, Inc., 180 F. Supp. 845, 848 (E.D. La. 1960), suggesting that the decision in Atmos Clock reflects the peculiarities of New York law. But see Maternally Yours, Inc. v. Your Maternity Shop, Inc., 234 F.2d 538, 545 (2d Cir. 1956) (concurring opinion) (denying that Atmos relies on New York law).

56.221 F.2d at 466.

57 See, e.g., Charles D. Bridell, Inc. v. Alglobe Trading Corp., 194 F.2d 416, 418 (2d Cir. 1952); Eastern Wine Corp. v. Winslow-Warren, Ltd., 137 F.2d 955 (2d Cir), cert. denied, 320 U.S. 758 (1943); Triangle Publications, Inc. v. Rohrlich, 167 F.2d 969, 980 (2d Cir. 1948) (dissenting opinion). Compare Standard Brands, Inc. v. Smidler, 151 F.2d 34, 41 (2d Cir. 1945) (concurring opinion), with id. at 37 (majority opinion).

58 Aro Mfg. Co. v. Convertible Top Replacement Co., 365 U.S. 336, 341 (1961); see id. at 347 (concurring opinion of Black, J., pointing out that Court is unanimous on the point). Compare the cases granting relief against a copyist who deceives no one but who enables his customers to deceive those who buy from them. E.g., William R. Warner \& Co. v. Eli Lilly \& Co., 265 U.S. 526, 530 (1924) (common law); FTC v. Winsted Hosiery Co., 258 U.S. 483, 494 (1922) (Federal Trade Commission Act). 59 This would appear to be the practical significance of the decision on remand, Mastercrafters Clock \& Radio Co. v. Vacheron \& Constantin-Le Coultre Watches, Inc., 123 U.S.P.Q. 381 (S.D.N.Y. 1959). The court of appeals had directed entry of an injunction and the award of damages; the trial court was further directed to determine whether the innovator was entitled to the copyist's profits made from the infringing clocks. $221 \mathrm{~F} .2 \mathrm{~d}$ at 467 . The district court then denied the latter, on the basis that there was no palming off by the copyist of his clocks as products of the innovator, nor any attempt to mislead the buyers, and the court left the innovator to prove whatever damages he had actually sustained. 123 U.S.P.Q. at 382 . Counsel for Mastercrafters has informed us that the parties have made an out-of-court settlement of the case. 
which would be made to these hosts can be hypothesized only on the theory that they would buy the $\$ 175$ clock if the $\$ 40$ clock were removed from the market-a dubious proposition. Loss of general reputation with guests, who might be potential Atmos customers, could occur if the guests were to conclude that Atmos must be an inferior clock when such tasteless people as their hosts own it-but this too is improbable. Arguably, potential customers aware of the existence of the $\$ 40$ imitation will refrain from buying the Atmos because it is being stripped of its snob appeal by the deceptive acts of 308-possessing (but cord-concealing) hosts. But the findings in Atmos contain not the slightest indication that this was in fact occurring-nor would there appear to be any practicable method to determine either the existence or the extent of such behavior. ${ }^{80}$

\section{An Analysis of tHe Cases}

We submit that a more precise analysis of the issues raised by unfair competition cases is called for than is revealed in these opinions. Such an analysis may, on the one hand, be productively formulated in terms of the respective roles of functionality, descriptiveness, and secondary meaning in the case. This approach leads to a "public injury" theory of the unfair competition cause of action. Alternatively, the analysis may be rested on the degree of protection warranted for the innovator who expends effort and money on developing a product or creating a market for it. This approach leads to a "misappropriation" theory of the unfair competition cause of action, a theory which, it is suggested below, is wholly unsatisfactory for resolving disputes in this area. Finally, a synthesis of these approaches might be essayed. But no court or commentator has attempted this, to the authors' knowledge, and the "public injury" and "misappropriation" doctrines are too antithetical to one another, we believe, to admit of mutual accommodation.

The first approach, based on presence or absence of functionality, descriptiveness, or secondary meaning, permits characterization of the possible fact patterns in cases in the following true-false tabular form:

60 Moreover, adjustment of the competing claims of snobbish consumers and their suppliers on the one hand, and of social climbers and their suppliers on the other, may well be a task for which courts-and perhaps even legislatures-are ill-suited. See note 54 supra; note 64 infra. This policy determination may readily be translated into the conclusion that the innovator's injury is far too remote from the act of deception properiy to be deemed the proximate result of the direct unfair competition. Cf. 2 HARPER \& JANES, TORTS \$20.4 (1956) (treating proximate cause as a public policy notion expanding or contracting relative to the value accorded the interest involved). 
TABLE I

\begin{tabular}{|c|c|c|c|}
\hline & Is Functional & Is Descriptive & Has Secondary Meaning \\
\hline$(1)$ & $\mathrm{T}$ & $\mathrm{T}$ & $\mathrm{T}$ \\
\hline$(2)$ & $\mathrm{F}$ & $\mathrm{T}$ & $\mathrm{T}$ \\
\hline$(3)$ & $\mathrm{T}$ & $\mathrm{F}$ & $\mathrm{T}$ \\
\hline (4) & $\mathrm{F}$ & F & $\mathrm{T}$ \\
\hline$(5)$ & $\mathrm{T}$ & $\mathrm{T}$ & F \\
\hline$(6)$ & $\mathrm{F}$ & $\mathrm{T}$ & $\mathrm{F}$ \\
\hline (7) & $T$ & F & $\mathrm{F}$ \\
\hline-- & ---- & ---- & $----\cdots$ \\
\hline$(8)$ & $F$ & $\mathrm{~F}$ & $\mathrm{~F}$ \\
\hline
\end{tabular}

The eight possible combinations ${ }^{61}$ fall into three main groups. In cases 1 through 3 , the copied feature both has secondary meaning and is functional or descriptive. In case 4 , the copying is of a sourceindicative, secondary-meaning feature only. In 5 through 8 , no secondary meaning is involved in what is copied, while in 8 , a subcategory of the last group, what is copied is not functional or descriptive nor does it have secondary meaning.

\section{A. "Palming Off": Neither Functionality Nor Descriptiveness}

The least perplexing problems are presented by case 4 . Here, no thing of value is made more readily available to the public; no useful description assists the prospective purchaser in his search. The copyist merely diverts the innovator's trade to himself while deceiving the public into thinking it is getting what it wants. Such "palming off" would appear to have little to recommend it.

61 This treatment presupposes a two-valued logic. The recognition of varying degrees of, say, descriptiveness or secondary meaning, ranging from zero to $100 \%$, presents greater problems of analysis than we believe appropriate, or, at any rate, practicable. But see the English cases, notes 128-35 infra and accompanying text. For an attempt in another legal field to replace two-valued logic with a continuous variable system, see Allen, Games Bargaining: A Proposed Application of the Theory of Games to Collective Bargaining, 65 Y ALE L.J. 660 (1956). 
Assuming that the copyist's product is priced below the original, however, the public is, arguably, benefited by getting merchandise equivalent to the "genuine" article at lower cost; in this view, even without a price differential no public harm would result if the copyist's product is at least equal in quality to the original. ${ }^{62}$ Underlying any conclusion that a copy really lowers price to the consumer, however, must be a finding of fact that, for the price, the copy is equal or superior in quality to the original (e.g., that it is three-quarters as good and half the price) - $a$ type of judgment that may tax the institutional capacity of courts. ${ }^{03}$ The presence of deception, moreover, raises a noneconomic consideration which certainly should not be ignored, ${ }^{\text {et }}$ and which, in our view, is determinative: respect for individual freedom of choice. ${ }^{85}$

It would seem that no sufficient countervailing advantage of more effective competition can be discerned which might justify the public deception involved in this type of case. Hence a balancing of interests is not required, since there is substantially nothing to balance against the harm of deception. To be sure, the copying could be permitted, provided a warning were placed on the product to alert prospective purchasers as to the true source of the goods. But since there is no serious public interest in this sort of copying, permitting it with a

02 See Eastern Wine Corp. v. Winslow-Warren, Ltd., 137 F.2d 955, 957 (2d Cir.), cert. dervied, 320 U.S. 758 (1943); Carolina Aniline \& Extract Co. v. Ray, 221 N.C. 269, 274, 20 S.E.2d 59, 62 (1942); Triangle Publications, Inc. v. Rohrlich, 167 F.2d 969, 980 \& n.13 (2d Cir. 1948) (Frank, J., dissenting); Standard Brands, Inc. v. Smidler, 151 F.2d 34, 41 (2d Cir. 1945) (Frank, J., concurring); Brown, Advertising and the Public Interest: Legal Protection of Trade Symbols, 57 Yale L.J. 1165 (1948).

63 Note, 70 Y ALE L.J. 406, 433 (1961); cf. Standard Oil Co. v. United States, 337 U.S. 293, 308, 310 (1949). To be sure, courts frequently face equally taxing problems in other areas, but the returns in prospect from making these particular judgments appear too slight to warrant the judicial expenditure entailed.

64 In Federal Trade Commission Act cases, under $\$ 5(\mathrm{a})$, the courts seem to have taken this view. See FTC v. Algoma Lumber Co., 291 U.S. 67, 78 (1934); Benton Announcements, Inc. v. FTC, 130 F.2d 254, 255 (2d Cir. 1942). Compare Eastern Wine Corp. v. Winslow-Warren, Ltd., 137 F.2d 955, 958 (2d Cir.), cert. denied, 320 U.S. 758 (1943), writh Standard Brands, Inc. v. Smidler, 151 F.2d 34, 41 n.13 (2d Cir. 1945).

65 We assume here that the copied feature identifies source, although the producer may not be individually known, and that the public cares enough who makes the goods to be moved in some degree to buy the product because of its source. In cases where a feature possessing some degree of source identification is copied, but where there is not the slightest reason to think that source would have any influence in motivating the buyer to buy (because, for example, what is involved is a cheap trifle bought on its face for what it seems to be), the considerations of buyer "freedom of choice" to which we have referred above are inapplicable. Solicitude for personal freedom of choice is appropriate when a "choice" is to be made, however unwise it may be, but not when there really is no "choice" because the buyer is utterly indifferent to the alternatives. In short, we think the law of unfair competition should not care about erroneous but academic (because they have no practical consequences) notions of source. Without buyer concern for source, source-indicative features involve for want of impact no "operative" facts. See generally Durable Toy \& Novelty Co. v. J. Chein \& Co., 133 F.2d 853 (2d Cir.), cert. denied, 320 U.S. 211 (1943), discussed in text accompanying notes 81-85 infra. 
warning serves, at best, no purpose. Thus courts and commentators generally agree that an innovator should have a cause of action against the copyist who attempts to palm his wares off as those of the innovator. ${ }^{68}$ In this area, at least, those who adhere to the traditional view and those who seek to extend the scope of the law are not in disagreement.

\section{B. Cases in Which Secondary Meaning Is Absent}

Categories 5 through 8 are alike in that the copied elements do not possess a secondary meaning that the products embodying them emanate from the innovator as their source; in 5, 6, and 7, moreover, the copied elements are functional or descriptive. Probably the most striking clash between those who believe that unfair competition law exists only to prevent public injury in the form of confusion of source and those who would use it to protect the "property rights" of "those who sow" against misappropriation by "those who reap" 67 occurs in these cases in which the product involved in the lawsuit is one about whose source the public is indifferent. In such cases the purchaser is never deceived as to the origin of the goods; there is no "palming off" of the newcomer's goods as those of the innovator.

\section{Cases Involving Functionality or Descriptiveness}

A primary goal of our economic system is promotion of the wide availability of useful goods at reasonable cost. ${ }^{68}$ To further this goal on a long-range basis, the system encourages authors and inventors to make their writings and discoveries available to the public by offering them the quid pro quo of the exclusive right for a limited term to market their innovations. ${ }^{69}$ Whether a purported functional innovation is substantial enough to merit the grant of exemption from the basic policy of competition is determined, in the first instance, by an agency created by statute for that purpose. ${ }^{70}$ If functional or de-

${ }^{60}$ E.g., Armstrong Paint \& Varnish Works v. Nu-Enamel Corp., 305 U.S. 315, 336 (1938); William R. Warner \& Co. v. Eli Lilly \& Co., 265 U.S. 526, 531-32 (1924). 67 See International News Serv. v. Associated Press, 248 U.S. 215, $239-40$ (1918). 68 See Northern Pac. Ry. v. United States, 356 U.S. 1, 4 (1958).

60 See U.S. Const. art. I, §8; 17 U.S.C. $\$ 1,101$ (1958); 35 U.S.C. §§ 154, 271(a) (1958).

70 See 17 U.S.C. $\$ \$ 201-02$ (1958) ; 35 U.S.C. $\$ \S 1-3,6-7,131-35$ (1958). Substantiality of innovation is scrutinized very carefully for mechanically functional innovations, and the patent grant is prima facie evidence that the claimed elements comprise a new and useful invention. See 35 U.S.C. $\$ 282$ (1958). When functionality is esthetic, however, the intensiveness of administrative scrutiny will vary with whether the protection sought is a design patent, see 35 U.S.C. $\$ 171$ (1958) ; Blisscraft of Hollywood v. United Plastics Co., 294 F.2d 694, 696-97 (2d Cir. 1961); Burgess Vibrocrafters, Inc. v. Atkins Indus., Inc., $204 \mathrm{~F} .2 \mathrm{~d} 311$ (7th Cir. 1953), or 
scriptive ${ }^{71}$ features are set apart from the public domain in the first instance by courts, without such an administrative scrutiny, there is a serious risk that the public will part with the competitive quo without being assured an adequate quid for consideration. Moreover, the grant resulting from a successful unfair competition action is perpetual, whereas the patent or copyright grant persists only for a limited term. Thus the dangers inherent in allowing unfair competition relief to be applied with respect to functional and descriptive elements, although not necessarily determinative of the issues, are clear. When no other public interest factor, such as that in preventing public deception, has been cast into the balance against the possible damage to the free enterprise system, courts have traditionally refused to forbid copying of functional or descriptive innovative elements. ${ }^{72}$ Under the misappropriation theory, however, a different result may be reached. ${ }^{73}$

Category 7 represents perhaps the most frequently litigated situation-the copyist who appropriates a functional feature of the innovator's product. The leading case in this area is Crescent Tool Co. v. Kilborn \& Bishop Co., ${ }^{74}$ involving the copying of the plaintiff's new and popular, but unpatented, "Crescent" wrench design. The plaintiff invoked the aid of the courts to protect the market that he had made or found against poaching by his rival, but he was not successful. Analogizing the distinctive appearance of the article to the descriptive

a copyright. In the latter case, scrutiny is not intensive. See 17 U.S.C. $\$ \S 11,207-09$ (1958); Burrow-Giles Lithographic Co. v. Sarony, 111 U.S. 53, 59 (1884).

Unlike esthetic functionality, for examples of which see Mazer v. Stein, 347 U.S. 201 (1954); Trifairi, Krussman \& Fishel, Inc. v. Charel Co., 134 F. Supp. 551 (S.D.N.Y. 1955), non-esthetic functionality is not protectable in the name of copyright. See Baker v. Selden, 101 U.S. 99 (1879) (accounting system) ; Brown Instrument Co. v. Warner, 161 F.2d 910 (D.C. Cir.), cert. denied, 332 U.S. 801 (1947) (chart not "writing" because it does not convey ideas); Affiliated Enterprises, Inc. v. Gruber, 86 F.2d 958 (1st Cir. 1936) ("Bank Night" concept not copyrightable). But cf. Globe Newspaper Co. v. Walker, 210 U.S. 356 (1908) (map). The rationale is essentially that the particular form of expression of the non-esthetic functionality involved is not what the "author" really seeks to protect-he seeks to protect the abstract idea instead, and this is outside the scope of "writings." See Mazer v. Stein, supra at 217.

The roles of patent and copyright in the protection of configurations of goods are compared generally in SchWARTZ, FrEe ENTERPRISE AND ECONOMIC ORGANIZATION 638-41 (2d ed. 1959).

71 Descriptiveness as such will not be protected by patent or copyright. It may receive incidental protection, however, to the extent that a descriptive package or emblem may be the subject of a copyright or design patent. Cf. Lucien Lelong, Inc v. Lander Co., 164 F.2d 395 (2d Cir. 1947) (denying protection after expiration of design patent to bottle shape which may have become generic or descriptive for cologne).

72 E.g., Societe Comptoir de L'Industrie Contonniere v. Alexander's Dep't Stores, Inc., 299 F.2d 33, 37 (2d Cir. 1962); see, e.g., Cheney Bros. v. Doris Silk Corp., 35 F.2d 279 (2d Cir. 1929), cert. denied, 281 U.S. 728 (1930); Chafee, Unfair Competition, 53 HARV. L. REV. 1289, 1317-18 (1940).

73 But cf. Callmann, He Who Reaps Where He Has Not Sozen, 55 HaRv. L. REv. $595,612-14$ (1942).

74247 Fed. 299 (2d Cir. 1917). 
title in certain trade name cases, ${ }^{75}$ Judge Learned Hand, speaking for the court, declared that the innovator could be protected against competition by the copyist only if the public had come to believe that Crescent wrenches came from a common source (which, of course, need not be individually known), and if they bought them because they wanted the goods that came from that source and no other. Since the "critical question of fact at the outset . . . whether the public is moved in any degree to buy the article because of its source" 76 was not established by plaintiff, relief was denied. Because the innovator failed to carry his proof far enough to establish that the design had acquired a secondary meaning, the court never even reached the question of "fair warning" versus deception (the copyist had clearly labelled his product as his own).

A more recent Second Circuit decision on copying functional features is Norwich Pharmacal Co. v. Sterling Drug, Inc., ${ }^{77}$ involving "Pepto-Bismol," the innovating stomach remedy, and "Pepsamar," the

75 See text accompanying note 12 supra. A distinction which might be urged between these cases and the Crescent Tool type of case is that the former typically involved words that had acquired their primary meaning in the public domain ("Glenfield" as a geographical designation, "camel hair" as the term applied to the hair of that beast), and then later acquired their secondary meaning, if any, after the plaintiff had appropriated the term to himself when applied in his particular context; in the Crescent Tool situation, however, the appearance of the product involved or its functional element is new and was not previously used in the public domain. But this distinction does not withstand closer scrutiny.

If the innovation is novel, in the sense that it did not previously exist in others' products, and yet the innovator elected to secure no patent, we believe that lack of patentability may be presumed. (In the alternative, the innovator elected to abandon his invention to the public. See McClain v. Ortmayer, 141 U.S. 419, 423-24 (1891); Pennock v. Dialogue, 27 U.S. (2 Pet.) 1, 22 (1829).) Bare novelty, however useful, is insufficient to warrant a patent. The alleged invention must also not be "obvious," see 35 U.S.C. $\$ 103$ (1958), which is to say it may not be the solution to the problem that other people skilled in the art might reasonably be expected to devise. See Great Atl. \& Pac. Tea Co. v. Supermarket Equip. Corp., 340 U.S. 147 (1950); Cuno Engineering Co. v. Automatic Devices Corp., 314 U.S. 84, 90 (1941) ; Hotchkiss v. Greenwood, 52 U.S. (11 How.) 248, 267 (1850). In short, absence of prior "existence" is not enough to warrant suspension of the rules of our competitive system; the claimed innovation must further not have previously "subsisted" or have been immanent in the art. For this reason, it cannot be premised that some novel functional element was not in the public domain merely because it was not already in use. Thus in Crescent Tool Judge Hand observed, "It will not be enough only to show how pleasing they [crescent wrenches] are, because all the features of beauty or utility, that commend them to the public are by hypothesis already in the public domain." 247 Fed. at 300.

Taking a word with one currency in the public domain and giving it a novel application, and hence a different or secondary currency, is not materially different from taking a common mechanical principle and applying it in a new way or taking a common design and applying it to the configuration of one's product. If, in either context, therefore, something more than the act of appropriation by the first comer is necessary to validate his claim to exclusive rights, the necessity is equal in both. Nor do we think any useful distinction between functionality and descriptiveness can be drawn on a premise that we enjoy a comparative wealth of words and a poverty of utilitarian product designs, thus warranting the recognition of different standards in the two fields.

76247 Fed. at 300 .

77271 F.2d 569 (2d Cir. 1959), cert. denied, 362 U.S. 919 (1960). 
nostrum which copied it. The innovator claimed that his rival had no right to copy the pink color of the product, but the court held that pink soothed the sensibilities of the suffering user and decreased the likelihood of his regurgitating the product. A finding of functionality would appear in order, the court reasoned, "because a rejected stomach medicine scarcely has a fair opportunity to fulfill its function." 78 The Pepto-Bismol case also involves category 6, since the court found that the "pep" common to "Pepto-Bismol" and "Pepsamar" was "an apocopate form of 'peptic,' pertaining to digestion," and generic for stomach remedies. ${ }^{79}$ Since secondary meaning for neither copied element had been established by the innovator, relief was denied. ${ }^{80}$

A more unusual example of descriptiveness in category 6 was presented in Durable Toy \& Novelty Corp. v. J. Chein \& Co., ${ }^{81}$ where the copied trademark "Uncle Sam" was descriptive for the copyist's product but not for the first user's. Plaintiff owned the registered trademark "Uncle Sam" for toy banks and put it on a "quality" line of various-shaped banks retailing at prices up to $\$ 2.50$ and covered by a lifetime guarantee. When defendant brought out a rudely made, tin, ten-cent toy bank, labelled "Uncle Sam Bank," shaped like a top hat, and painted red, white, and blue, the senior user of the mark brought

78271 F.2d at 572.

70 Id. at 573 .

80 The court's analysis in the Pepto-Bismol case is more troublesome than the text indicates. While the result reached, and much of the reasoning, reflected the traditional, "public injury"-oriented conception of unfair competition law, some attempt was made to defer to the newer view which had gained acceptance in New York law. See notes 29-31 supra, 140-49 infra and accompanying text. In an effort to dissipate misunderstanding which had grown up about the essential elements of an unfair competition cause of action without secondary meaning, the court sought to rationalize the newer view and distinguish prior cases in terms of categories of "predatory practices," viz., "palming off," "actual deception," and "appropriation of another's property." See 271 F.2d at 571.

We do not believe that this analysis, however ingenious, is wholly satisfactory. For example, one of the court's new predatory categories, "palming off," is a wellknown term of art in unfair competition law, see 3 RestateMEnT, TORTs 539 (1938), which refers precisely to the traditional conception of unfair competition embodying the requirement of secondary meaning (as exemplified by the Crescent Tool case). See Speedry Prods., Inc. v. Dri Mark Prods., Inc., 271 F.2d 646, 650 (2d Cir. 1959) (using "palming off" in the traditional sense three days earlier). But see Note, 70 YALE L.J. 406, 428-29 (1961) (missing the point). Moreover, the distinction between "palming off" and "actual deception" is, at best, tenuous. Finally, the court's attempt to fit the line of misappropriation cases into the three categories appears to strain for distinctions based on fairly casual elements of the fact situations, although, to be sure, it does have the virtue of disposing of the cases.

The court's technique thus disguises, without resolving, the public injury-private wrong conflict whose disruptive effect on New York law it felt so keenly. The inadequacies of the approach would seem largely due to the unsusceptibility of the New York law to satisfactory rationalization. See text accompanying notes 148-50 infra. Supporters of the misappropriation doctrine are also critical of the analysis in Pepto-Bismol. See Derenberg, The Thirteenth Year of Administration of the Lanham Trademark Act of 1946, 50 TRADEMARK REP. 773, 845-46 (1960); Note, 70 YALE L.J. 406, 428-29 (1961).

81133 F.2d 853 (2d Cir.), cert. denied, 320 U.S. 211 (1943). 
an action for an injunction and damages. On appeal from a favorable verdict for the innovator, the Second Circuit reversed, per Learned Hand:

There is no basis for the assumption that anyone who bought one of the defendants' banks would be led to do so because he supposed that the plaintiff was its source. . . . There is no reason to believe that anyone who bought the defendants' tawdry little gadget . . . has ever supposed that "Uncle Sam's" meant the plaintiff, or that it signified to him any single source whatever. Moreover, even if he had so supposed, there is not the slightest reason to think that it would have had any influence in determining him to buy; and every reason to believe that it would not. Such cheap trifles are bought on their face, so to say: for what they seem to be. Those who buy them care nothing who makes them.... ${ }^{82}$

For the plaintiff, "Uncle Sam" was used merely "to throw about its banks a vague implication of solidity," and to appropriate whatever advantage there may be in exploiting the national mythology set about the patriotic symbol. ${ }^{83}$ But for defendant, the red, white, and blue top hat was very aptly described by "Uncle Sam." The court did not deem it necessary to balance the descriptivity to the copyist against the property right claims ${ }^{84}$ of the senior user, however, for it simply denied that he had any "right," for want of secondary meaning in the mark. . $^{\mathbf{5}}$

The celebrated litigation between Superman and Captain Mar$\mathrm{vel}^{86}$ furnishes an interesting example of category 5. Whiz Comics had taken Action Comics' character "Superman," put red tights on him in place of blue tights, changed his red cape for a yellow one, replaced the letter "S" on his chest medallion with a bolt of lightning, and then renamed him "Captain Marvel." That defendant imitated plaintiff by putting a benevolent Hercules figure into comic strip form was clearly

82 Id. at 854 .

$83 \mathrm{Id}$. at 855 .

84 See $i d$. at 854 .

85 Accord, Selchow \& Righter Co. v. Western Printing \& Lithographing Co., 142 F.2d 707, 709 (7th Cir.), cert. denied, 323 U.S. 735 (1944) (descriptive mark under ten-year clause of Trademark Act of 1905, ch. 592, \$ 5, 33 Stat. 725). See also Rytex Co. v. Ryan, 126 F.2d 952 (7th Cir. 1942); Sylvania Elec. Prods., Inc. v. Dura Elec. Lamp Co., 144 F. Supp. 112, 121-22, 128 (D.N.J. 1956), aff'd, 247 F.2d 730 (3d Cir. 1957). Compare Societe Comptoir de L'Industrie Cotonniere v. Alexander's Dep't Stores, Inc., 299 F.2d 33 (2d Cir. 1962), permitting the copyist to label his dresses as copies of Dior models, which they were. Descriptive use of the Dior trademark had considerable influence, unlike the use of "Uncle Sam," in motivating the customers to buy; but, like the buyers of the imitation Atmos clock, see text following note 50 supra, the dress buyers knew what they were doing.

${ }^{86}$ National Comics Publications, Inc. v. Fawcett Publications, Inc., 191 F.2d 594 (2d Cir. 1951) (L. Hand, J.). 
not unfair competition, since the figure is a stock character long since in the public domain. The costume of plaintiff's character, however-the set of tights, cape, chest medallion-is a trademark of sorts, or at least a distinctive configuration of goods. ${ }^{87}$ To the extent that this costume has become descriptive for comic strip figures of this class, the public interest in facilitating consumer recognition of the goods would strongly suggest that it be kept free to all comers (Wonder Woman, Mighty Mouse, et al. $).^{88}$ Again, to the extent that the costume is part of what makes the strips attractive, the Superman uniform is functional and should be kept in the public domain.

Without reaching these questions of public policy, however, the court found the claim of unfair competition baseless for want of secondary meaning. No balancing of interests was necessary because the public interest in preventing buyer deception was not involved. A determination of likelihood of public deception would have required, as we have seen from Crescent Tool, secondary meaning in the Superman uniform-that the uniform had become associated with the innovator as the source and that this association provided an inducement for buyers to deal with him. But "in the case of these silly pictures," as the court characterized them, "nobody cares who is the producer." 89 The pictures sold because they were functional-they amused and pleased-and this was, as Judge Hand put it, because of "what they are, not because they come from [the plaintiff] . . . ." 90 In these circumstances, therefore, the innovator asserted no claim which should call the power of the state into action on his behalf.

The application of the misappropriation theory to cases in these categories is illustrated by Flint v. Oleet Jewelry Mfg. Co., ${ }^{91}$ a case involving facts quite similar to those in Crescent Tool. Plaintiff had invented, but neither copyrighted nor patented, a locket composed of a mustard seed encased in clear plastic. The locket was supposed to remind its wearer of the Biblical passage concerning the power of "so much faith as a grain of mustard" to move mountains. ${ }^{92}$ This "Mustard Seed Remembrancer" was copied by defendant, who marketed "Your Mustard Seed Charm." Despite the obvious func-

87 To be sure, no technical trademark is involved, for want of affixation to the goods. See Gray v. Armand Co., 24 F.2d 878 (D.C. Cir. 1928). But cf. Lanham Act $\$ 45,60$ Stat. 444 (1946), 15 U.S.C. $\$ 1127$ (1958) (mark used in commerce). Again, just what "the goods" are, the comic book or the character, to which the mark should be affixed, is problematical.

88 But see Detective Comics, Inc. v. Bruns Publications, Inc., 111 F.2d 432 (2d Cir. 1940) ("Wonderman" infringes copyright on Superman's costume and feats).

89191 F.2d at 603.

90 Ibid.

91133 F. Supp. 459 (S.D.N.Y. 1955).

02 Matt. 17:20. 
tionality of the locket, and the descriptiveness of its name and of the accompanying literature, the court enjoined the activities of the copyist, holding that secondary meaning was no longer an essential element of unfair competition in New York. The decision was not appealed from the district court to the court of appeals, where perhaps it might have fallen to Judge Hand to write the opinion for the court. Clearly, it would have been hard to accommodate the result in Flint ${ }^{93}$ to the philosophy and language of the Chein ${ }^{94}$ and Superman ${ }^{95}$ cases. By the same token, however, a true believer in the misappropriation doctrine would probably reach the opposite result in every one of the cases discussed in the last several pages. ${ }^{96}$ Thus, in the Atmos and Notre Dame cases, which fall within these categories of our classification, the courts readily bypassed the public interest considerations protected in the Hand decisions when they collided with the private interests of innovators.

\section{The Neutral Case}

Different considerations might be thought to apply to the eighth category, the "neutral case," in which the copied element is neither functional nor descriptive, nor has it acquired a secondary meaning. The case for protecting the innovator against copying despite the absence of secondary meaning can be made out most strongly here, since the affirmative public interest in keeping the area free is not obvious. But the traditional view-that the burden of persuasion is not on the copyist, since the presumption in favor of free competition is on his side, but on the innovator who must persuade the court to validate his claims-has, we submit, more to recommend it. According to the philosophy of the "public injury" rule, which we advocate, the courts should not interfere in private controversies in which one trader seeks to control the marketing of another unless the interference is calculated to further the interest of the public at large. In the neutral case, then, the state should leave the parties where the free marketplace leaves them.

93 An additional element involved in Flint was the copyist's false and perhaps deceptive assertion that he had originated the locket. Although the district court specifically relied upon the New York misappropriation law, the case has been distinguished on the basis of presence of deception, apparently on the theory that Flint deserves to be restricted to its facts. See Norwich Pharmacal Co. v. Sterling Drug Co., 271 F.2d 569, 571 (2d Cir. 1959), cert. denied, 362 U.S. 919 (1960); cf. Speedry Prods., Inc. v. Dri Mark Prods., Inc., 271 F.2d 646, 650 \& n.2 (2d Cir. 1959). Bitt see text accompanying note 139 infra. See also American-Marietta Co. v. Krigsman, 275 F.2d 287, 289 (2d Cir. 1960).

94 See text accompanying note 82 supra.

95 See text accompanying note 89 supra. (1961).

96 See Derenberg, supra note 80, at 773, 845-49; Note, 70 YALE L.J. 406, 418-30 
Our basic reason for this position is the belief that state inaction is to be preferred to state action when all other things are equal (whether equal in fact because public interests are equipoised on either side or equal by default because there is not sufficient information to support an informed opinion). It is recognized that public consequences flow from withholding state action just as they do from affirmatively exercising state power. But we think that the possible collateral results ${ }^{97}$ of affirmative action by the state dictate a policy of judicial self-restraint and tip the balance in otherwise neutral cases toward inaction. ${ }^{98}$ By the same token, we prefer a wider diffusion of the power to make decisions, or a maximization of the exercise of individual volition. ${ }^{99}$ And, as between the many businessmen and the few courts, we prefer to spread the responsibility out among the former unless a convincing case is made for the latter to step in.

Cases in the eighth category are infrequent, for the copyist seldom copies without some reason-taking advantage either of the functionality of the innovator's product or of its secondary meaning. More frequently, however, courts refer to category 8 in dictum in the course of a decision in a category 7 case. Thus in Crescent Tool Judge Hand observed, in passing, "The defendant has as much right to copy the 'nonfunctional' features of the article as any others, so long as they have not become associated with the plaintiff as manufacturer or source." 100

The recent "sponge mop" case, American-Marietta Co. v. Krigs$\operatorname{man},{ }^{101}$ does illustrate this category, however, as well as suggest some

97 In this respect we place particular importance on the "right to be let alone-the most comprehensive of rights and the right most valued by civilized men," referred to in the dissenting opinion of Brandeis, J., in Olmstead v. United States, 277 U.S. 438,478 (1928). See also the dissenting opinion of Douglas, J., in Public Util. Comm'n v. Pollak, 343 U.S. 451, 467 (1952). We believe with Mr. Justice Holmes that "the most enlightened judicial policy is to let people manage their own business in their own way, unless the ground for interference is very clear," Dr. Miles Medical Co. v. John D. Park \& Sons Co., 220 U.S. 373, 411 (1911) (dissenting opinion), rather than with Callmann that "to justify any regulation of competition, it need not be shown that it is positively advantageous to the public, but only that the public is not harmed thereby," note 73 supra, at 599. Compare KNIGHT, FrEedom AND Reform 369 (1947) ; Kessler, supra note 46, at 167 , quoted infra in text accompanying note 156.

98 See generally Hayer, The Constitution of Liberty 218 (1960); Wallich, The Cost of FreEdom 62-63, 71-73 (1960). By analogy, we have the familiar distinction between negative and affirmative acts. Although the lack of logical distinction between a promise and the absence of the contrary promise may be demonstrated, see Stone, Burden of Proof and the Judicial Process, 60 L.Q. REv. 262, 280-81 (1944), we think all lawyers recognize a pragmatic distinction between ordering someone to do something and ordering him to refrain from doing something, a distinction based essentially on what constitutes disturbing the status quo.

99 See Brewster, The Corporation and Economic Feneralism 75-76 (1959); KNIGHT, FREEDOM AND REFORM 53-54 (1947).

100247 Fed. at 300 .

101275 F.2d 287 (2d Cir. 1960), modifying 170 F. Supp. (E.D.N.Y. 1959), modifying 168 F. Supp. 645 (1958). 
of the practical consequences of the allocation of the burden of proof in these cases. After the patent on the sponge mop which has largely replaced the old-fashioned string mop was invalidated, the former licensee attempted to secure protection in the name of unfair competition. ${ }^{102}$ But protection of the functional features of the novel mop was not sought; plaintiff attempted only to prevent the copying of the nonfunctional arrangement of slots in the metal "presser plate" (hinged to the bottom of the mop) which is pressed against the sponge to squeeze water out. Nevertheless, the preliminary injunction was denied. The rule against nonfunctional copying, the court of appeals held (speaking through Judge Hand), is restricted to cases where the nonfunctional element has acquired a secondary meaning:

. . . It is indeed quite likely that buyers have assumed an identity of origin to the two mops from their general similarity; it is even possible-though we should suppose it very unlikely-that the identical form of the "slots" may have contributed to that assumption, but one who seeks to enjoin the reproduction of what is in the public domain must affirmatively show that the copied features were the reason for the confusion; it is not enough that perhaps it may have contributed .... 103

The practical consequence of placing on the innovator the burden of bringing forward persuasive evidence of secondary meaning, imposing on the copyist no burden of showing functionality or descriptiveness until the innovator has made out his part of the case, is evident. Often neither party can prove anything, ${ }^{104}$ and the allocation of burden of proof in category 8 is, and in categories 5-7 often is, ${ }^{105}$

102 Plaintiff had been the domestic licensee of the patent during its period of apparent validity, from 1949 to 1957 . When plaintiff terminated its license arrangement in 1957 because of the invalidation, the inventor began selling the component parts of the mop to defendant, who assembled and marketed the product. $168 \mathrm{~F}$. Supp. at 647. Plaintiff then sued to protect the flourishing market it had built up in the United States for the sponge mop by "extensive advertising and efficient sales methods." $170 \mathrm{~F}$. Supp. at 772 .

103275 F.2d at 290 .

104 See MCCormick, Evidence $\$ 322$, at 686 (1954). The classic example of this is Gray v. Gardner, 17 Mass. 188 (1821). See also Holden v. Bloom, 314 Mass. 309, 50 N.E.2d 193 (1943); Union Oil Co. v. Lull, 220 Ore. 412, 349 P.2d 243 (1960); Winans v. Attorney General, [1904] A.C. 287, 289; Munro, Brice \& Co. v. War Risks Ass'n, [1918] 2 K.B. 78; In re Aldersey, [1905] 2 Ch. 181, 187-88. See generally Fuller, Basic CoNTract LAW 767-68, 770 (1947).

105 Thus, in Crescent Tool (in category 7), in Chein (in category 6), and in Superman (probably in category 5), the court never reached functionality or descriptiveness (although functionality was presumed in Crescent Tool and, apparently, in Superman) because the plaintiff never proved "the absolute condition to any relief whatever." 247 Fed. at 300 . To be sure, descriptiveness or functionality can be proved, as in DuPont Cellophane Co. v. Waxed Prods. Co., 85 F.2d 75 (2d Cir.), cert. denied, 299 U.S. 601 (1936) ("cellophane" descriptive or generic for cellulose film), but it is much more common to let it be assumed, as with pinkness of PeptoBismol, whereupon the case goes off on plaintiff's failure to make out his affirmative 
determinative of the issues. ${ }^{108}$ This determination, however, is fully consistent with the policy considerations outlined previously, for it gives functionality the benefit of the doubt and minimizes the incidence of state action. And allocation of the burden of proof, like adoption of presumptions, is a familiar means of expressing policies. ${ }^{107}$

\section{Cases Involving Competing Values}

Categories 1 through 3 present the greatest difficulties in analysis. Here, the public interest in preventing consumer deception and the interest in freeing descriptive and functional features clash; the ease of balancing something against nothing, found in category 4 and categories 5-7, is absent. The short answer to the problem is to take refuge in a case-by-case analysis, by means of which the solution appropriate to each peculiar set of facts is developed. ${ }^{108}$ This approach leaves unstated, however, the standards for making the comparisonand therefore, as some may view it, leaves too much room for individual caprice ${ }^{109}$ and too much uncertainty for the businessmen affected..$^{110}$ Moreover, hard cases like these, where all the operative factors are involved, and compete for primacy, test the validity of the doctrines

case on secondary meaning. We suspect that some of these category 5-7 cases might have gone the other way if plaintiff had met his burden of showing some secondary meaning and thus turned them into category 1-3 cases.

${ }_{108}$ See Chas. D. Bridell, Inc. v. Alglobe Trading Corp., 194 F.2d 416, 421-22 (2d Cir. 1952) (dissent protests readiness of majority to take judicial notice of absence of secondary meaning and concludes that almost nothing could make them believe secondary meaning existed); Triangle Publications, Inc. v. Rohrlich, 167 F.2d 969, 976-77 \& nn.6, $7 \&$ 7a (2d Cir. 1948) (dissenting opinion). In addition to the absolute difficulties of proof, say, of secondary meaning, the cost of bringing evidence forward may be very stubstantial. Compare the cost-justification problem under the Robinson-Patman Act $\$ 2$ (a), 49 Stat 1528 (1936), 15 U.S.C. $\S 13$ (a) (1958), discussed in Atr'y Gen. NAT'L Comm. Antrtrust Rep. 172-74 (1955) ("only the most prosperous and patient business firm could afford pursuit of an often illusory defense"); Austern, Tabula in Naufragio-Administrative Style, in 1953 ANTTTRUST SYMPOSIUM 105,115 (available only to "the wealthy, the resourceful and the tireless").

107 See Stone, supra note 98.

108 Another short answer is to treat secondary meaning as the ultimate fact rather than an evidentiary (or at least subsidiary) fact, subsuming and concealing the whole analysis in the determination of secondary meaning vel non. See Midwest Plastics Corp. v. Protective Closures Co., 285 F.2d 747, 750 (10th Cir. 1960); Upjohn Co. v. Schwartz, 246 F.2d 254, 256 (2d Cir. 1957) ; J. R. Clark Co. v. Murray Metal Prods. Co., 219 F.2d 313, 320 (5th Cir. 1955); Alan Wood Steel Co. v. Watson, 150 F. Supp. 861,862 (D.D.C. 1957). It would appear clear that a feature of a product can play a role in its operation and at the same time identify its source. See, e.g., William Edge \& Sons v. William Niccolls \& Sons, [1911] A.C. 693. But courts usually deny that a functional feature can operate as a trademark. See, e.g., United States Plywood Corp. v. Watson, 171 F. Supp. 193 (D.D.C. 1958) ; Sylvania Elec. Prods., Inc. v. Dura Elec. Iamp Co., 247 F.2d 730, 732-34 (3d Cir. 1957) (alternative holding). Compare with the foregoing cases the far more carefully articulated analysis of Application of Deister Concentrator Co., 289 F.2d 496, 500, 503-04 (C.C.P.A. 1961).

109 For the view that case-by-case analysis (in an antitrust law context) may readily degenerate into no analysis at all, see Kessler \& Stern, Competition, Contract, and Vertical Integration, 69 YALE L.J. 1, 66 n.295 (1959). See also Levi, Mergers, in Conference on the Antitrust Laws and the Att'y Gen. Nat'l Conm. AntiTRUST REP. 69, 77 (Rahl \& Zaidins ed. 1955).

110 Aro Mfg. Co. v. Convertible Top Replacement Co., 365 U.S. 336, 358 (1961) (Black, J., concurring). 
applied in situations in which the difficulties of analysis are less taxing. ${ }^{111}$ Refusal to face the problems of balancing the competing policies and values at stake in such cases amounts to abdication of the judicial function. Both the business community and the general public are entitled to overt, articulated analysis of the lawmaking process. ${ }^{112}$

The courts have escaped from the pitfalls of the short answer by singling out a further pair of operative facts to be considered in cases involving the copying of features which both possess secondary meaning and are functional or descriptive. These are whether a fair warning to the purchaser is feasible, and whether it is provided. When fair warning is given the buyer, copying is allowed. ${ }^{113}$ When the warning is feasible and is not given, the copying is deemed impermissible. When the warning is not feasible, however, the necessity of balancing competing values again becomes acute. The solution proposed in the Restatement for such cases is not to balance values in each case as it arises, but to strike an a priori balance with the public interest in unfettered competition given a preferred position. ${ }^{\text {114 }}$ The few English cases take an opposite view. ${ }^{115}$

The "fair warning" rule has been applied by the courts in descriptiveness and functionality cases alike. In DuPont Cellophane Co. v. Waxed Prods. Co., ${ }^{116}$ the court faced the problem of determining what degree of protection should be given to the trademark "Cellophane" after it had become generic for cellulose film. Despite the fact that the term was now descriptive, it still retained some secondary meaning, at least to some buyers. Hence the relief given the innovator was to require the rival Sylvania to refer to his product as "Sylvania's cellophane." ${ }^{117}$ In Modern Aids, Inc. v. R. H. Macy

111 See Corbin, Hard Cases Make Good Law, 33 Yale L.J. 78 (1923).

112 See Kessler, Arthur Linton Corbin-A Tribute, 64 Y ALE L.J. 164, 166 (1954).

113 One may regard the warning as a device to negate source-identification-in which case the presence of "fair warning" would be deemed to shift cases in categories 1-3 into 5-7. The writers believe it more helpful to consider this matter apart from the question of whether the copied element is source-identificatory, rather than assimilating it to the complex judgment of secondary meaning. The source-identificatory and functional (or descriptive) element may well, for example, be distinct from the manner of warning. Thus, the body design of the Atmos clock might be copied, but the carton and the dial face labelled "made by Mastercrafters, who have no connection with Atmos."

114 Restatement, Torts $\$ 741$ (b) (ii), comment $j$ (1938).

115 See text accompanying notes 128-35 infra.

11685 F.2d 75 (2d Cir.), cert. denied, 299 U.S. 601 (1936).

117 The solution in G. \& C. Merriam Co. v. Saalfield, 198 Fed. 369 (6th Cir. 1912), cert. denied, 243 U.S. 651 (1916), was similar. The text of Noah Webster's dictionary had passed into the public domain after the copyright had expired, and the original publisher was faced by a rival. The court permitted the copyist to term his dictionary a "Webster's," since it indeed was Noah's product, but the newcomer was required to state that he was not the "original" publisher. The general principle has elsewhere been expressed: "[T] he explanation must accompany the use, so as to give the antidote with the bane." Herring-Hall-Marvin Safe Co. v. Hall's Safe Co., 208 U.S. 554, 559 (1908). But cf. Reddaway v. Banham, [1896] A.C. 199; Montgomery v. Thompson, [1891] A.C. 217,225 (MacNaghten, L.J.: "Thirsty folk want beer, not explanations ..."). 
\& Co. ${ }^{118}$ the defendant had copied plaintiff's massage machine. The district court enjoined the copyist from selling the machine or any similar machine. But the court of appeals reversed, since defendant was free to imitate plaintiff's machine "as closely as it chose," unless (1) the configuration of the machine had acquired a secondary meaning implying the innovator as the source, and (2) this source, rather than the machine itself, was what moved purchasers to buy. "Even then, however," the court held, "relief would go no further than to require the defendant to make plain to buyers that the plaintiff was not the source . . . " 119

The more difficult problem is posed by the case where adequate source warning is not commercially feasible, and therefore is not given. The conflict between the public interest in freeing descriptive or functional features conflicts directly with the public interest in preventing consumer deception. The copyist, of course, champions the former value; the innovator asserts the latter. One solution would be to attempt to measure and compare the two interests. We have already alluded to the difficulties of this approach; although they may not be insurmountable, they certainly make this solution infelicitous. ${ }^{120}$

Another, and ideal, solution would be to find one or more additional operative facts to bring into the analysis to eliminate further necessity for case-by-case balancing, just as the introduction of the concept of "warning" helped to do at the immediately prior stage of analysis. Unfortunately, no one has come up with such helpful additional categories for schematizing this sector of unfair competition law. Moreover, addition of another category or two would probably only push the case-by-case balancing a little further away, rather than eliminate it. In the end one must, we suspect, choose between one type of fiat or another-the balancing of the equities, subject to no review but for abuse of discretion, or the $a$ priori choice of one value as always prime-to put an end to the infinite regress from the element of choice. ${ }^{121}$

The leading case here is Shredded Wheat Co. v. Humphrey Cornell $\mathrm{Co}_{0 .}{ }^{122}$ a suit between the innovator of shredded wheat and a

118264 F.2d 93 (2d Cir. 1959).

119 Id. at 94.

120 It should be noted, however, that when the area of balancing intangibles is narrowed to this degree, the unpalatableness of this resort is correspondingly lessened.

121 Cf. Henkin, Shelley v. Kraemer: Notes for a Revised Opinion, 110 U. PA. L. REv. 473, 505 (1962). Moreover, the practice of adding more concepts, like epicycles to a Ptolmaic system to shore it up must eventually be discarded and a Copernican system adopted instead. The policy of Occam's Razor-terminological parsimony $\rightarrow$ is sound. The more legal concepts that are involved in the analysis, the more confusion and likelihood of contradictions.

122250 Fed. 960 (2d Cir. 1918). 
copyist. The evidence was uncontradicted that the innovator's shredded wheat biscuit had acquired a secondary meaning. But when restaurants and boarding houses served the biscuits in cereal bowls to diners there was no way for the patrons to be sure they were getting the "original" shredded wheat, if they cared (as, indeed, some did) from what source their breakfast emanated. Although it was "physically possible" to affix a distinguishing feature to the newcomer's biscuit that would apprise purchasers of the source, the practicality of such measures was doubtful. To bake the biscuit a darker brown, or else make it rawer and thus lighter in hue, would render it "repellent to most tastes." To enlarge the biscuit would make it too big to put in a cereal bowl; to make it smaller, so three biscuits would be eaten instead of the present two, would substantially increase manufacturing costs. It was suggested that the biscuit itself could have a mark impressed into it or a label pasted on it, but the feasibility of such devices was uncertain. In an effort to adjust the competing interests, the Second Circuit, speaking through Judge Learned Hand, required the copyist to attempt to put some kind of warning on his biscuits during a six-month probationary period. At the end of that time, the copyist was to be relieved of the restriction if he showed that it made impossible his continued competition with "an assurance of reasonable profit."

The Restatement takes a similar position, but appears to employ a standard of reasonable feasibility somewhat more tolerant to the copyist. It requires the copyist of functional features with secondary meaning to take "reasonable steps to inform prospective purchasers that the goods which he markets are not those of the other." ${ }^{123}$ Those steps which "would involve a financial expenditure which would substantially hinder competition" or "cannot be taken as a practical matter" are not deemed "reasonable." ${ }^{124}$ This view appears to be based on the language of Mr. Justice Brandeis in a later shredded wheat case, Kellogg Co. v. National Biscuit Co., ${ }^{125}$ in which the Court relieved the copyist Kellogg of any burden to distinguish its biscuits from the "originals." The copyist was held not to be obliged "to insure that every purchaser will know it to be the maker but to use every reasonable means to prevent confusion." 126

123 Restatement, Torts $\$ 741$ (b) (ii) (1938).

$124 I d$., comment $j$.

125305 U.S. 111 (1938).

126 Id. at 121. Among the facts which the Court deemed relevant in finding that no further steps by the copyist were reasonably required were that the copied biscuits were $\%$ the size of the original, that $2 \frac{\pi}{2} \%$ of Kellogg's sales were to restaurants, and that, of this $2 \% / 2 \%$, some $98 \%$ of it was sold in labelled, individual-serving cartons. Moreover, the cost of changing from the functional, pillow-shaped biscuit to another 
A contrasting solution to the problem was reached in some English cases. These appear to emphasize the comparison of the "equitable rights of rival traders" to the exclusion of other factors, thus foreshadowing the American "misappropriation" doctrine. ${ }^{127}$

In Montgomery $v$. Thompson, ${ }^{128}$ the first comer had operated the only brewery in Stone for over a century, and "Stone ales" had achieved a national reputation for quality. According to the newcomer, only the peculiar virtue and chemical qualities of Stone's waters had attracted him to that town as a brewery site. Although the court recognized that some degree of description was involved, and several lords expressed reservations about the breadth of the lower court's injunction against use of "Stone," the innovator's claims were upheld. As for the copyist's contention that he should be permitted to sell "Stone ale" with a notice on the label that it did not emanate from the plaintiff, Lord MacNaghten doubted the effectiveness of any warning in the circumstances of the case: "Thirsty folk want beer, not explanations. If the public get the thing they want, or something near it, and get it under the old name-the name with which they are familiar-they are likely to be supremely indifferent to the character and conduct of the brewer and the equitable rights of rival traders." 129

In Reddaway $v$. Banham, ${ }^{130}$ the court forbade a copyist to label his machinery belts "camel hair belting," even though it turned out in the course of trial (as no one in the trade had suspected) that camel hair was a principal constituent of the raw materials. No one really cared, however, what the belts actually contained, and other manufacturers indifferently labelled their belting "Buffalo," "Crocodile," "Yak," "Gnu," or whatever animal, hairy or hairless, took their fancy. It was clear to the court that no warning would be effective (many buyers did not speak English) and that the only effect of permitting the copyist to use the (technically) descriptive phrase would be to allow him to

form would be significant. Id. at 121-22. Among the considerations which would generally enter the determination of whether a warning requirement was feasible are "the interest of the public in the advances of technical progress and economic competition, the degree of similarity in the rival products, the alternate means of production available, the nature and cost of the product, the type of customers generally involved, and the negotiations and care usually employed prior to making a purchase." American Safety Table Co. v. Schreiber, 269 F.2d 255, 274-75 (2d Cir.), cert. denied, 361 U.S. 915 (1959).

127 A similar solution is referred to in Note, 70 Y ALE L.J. 406, 436-37 (1961) -requiring that the rival manufacturers' products be distinguished, even if this means that the newcomer must not use functional or descriptive features.

128 [1891] A.C. 217.

$129 \mathrm{Id}$. at 225 . The reader is invited to speculate how the Stone ale opinion would have been written by Judge Learned Hand, particularly with reference to the degree of protection appropriate for a manufacturer to whom (or to whose "equitable rights") his patrons are "supremely indifferent" so long as they get "something near" his product.

130 [1896] A.C. 199. 
deceive the first comer's customers, to whom "camel hair" had the secondary meaning that Reddaway was the source of the goods, and to whom the copyist had given no "fair warning." 131

In the more recent Spanish Champagne case, Bollinger v. Costa Brava Wine Co., ${ }^{132}$ twelve of the great French champagne houses brought an action to enjoin the defendant from selling Spanish sparkling wine (known in Spain as "perelada") under the label "Spanish Champagne." There was a suggestion at trial that the bride's mother would be more concerned with spending money on the trousseau than on the wine, and would therefore take advantage of the fact that her guests would not inquire too closely into the origin of what they were drinking. ${ }^{133}$ Fearing that the guests would be too thirsty, or would otherwise lack the opportunity, ${ }^{134}$ to question what they were being served, or, in Lord MacNaghten's words, to weigh "the equitable rights of rival traders," the High Court entered an injunction banning the use of the word "champagne" on the perelada label. ${ }^{135}$ There was no discussion of the feasibility of giving fair warning or whether in fact it was given by the use of the prefix "Spanish." For the sake of discussion, we assume here that fair warning was not given and (as in Stone ale) was not feasible.

In at least the first two English cases, the facts are distinguishable from the American cases, in that the descriptiveness was deemed slight or even accidental, whereas the secondary meaning was substantial. Assuming that premise, the impairment of the public interest by the grant of protection appears insignificant. The Spanish Champagne case, however, raises more questions. In this country, all sparkling white wines are called champagnes, and we venture to suggest that if they were not, few buyers would know what they were. ${ }^{136}$ To be sure,

131 Id. at 221-22.

132 [1961] 1 Weekly L.R. 277 (Ch. 1960). See also the interlocutory decree on demurrer, [1960] Ch. 262 (1959).

133 See the remarks of A. G. Guest during a broadcast on the Third Programme, summarized in $A$ Case of Champagne, 65 THE IISTENER 927, 930 (1961).

134 Compare G. H. Mumm Champagne Co. v. Eastern Wine Corp., 142 F.2d 499 (2d Cir.), cert. denied, 323 U.S. 715 (1944), in which Judge Hand recognized the propensity of unscrupulous restaurateurs to furnish a cheap grade of champagne to patrons well in their cups and thus unable to distinguish what they were drinking (defendant's wine) from what they were paying for (plaintiff's).

135 Compare Restatement, ToRTs $\$ 720$ (a) (1938). See also Whitstable Fishery Co. v. Hayling Fisheries, Ltd., 17 R. Pat. Cas. 461 (1900); Free Fishers \& Dredgers of Whitstable v. Elliott, 4 T.I.R. 273 (Ch. 1888), both distinguished in the principal case.

136 See 27 C.F.R. $\$ \$ 4.21$ (b) 2-3, 4.25 (1961) (Internal Revenue Service regulations under the Federal Alcohol Administration Act allowing domestic sparkling white wine to be labelled "champagne" in specified circumstances). Compare S. Con. Res. 35, H.R. Con. Res. 356, 87th Cong., Ist Sess. (1961) (favoring exclusion from the United States of foreign liquor labelled "bourbon"); 107 CoNG. REC. A2383 (1961) (remarks of Rep. Watts of Kentucky to the same effect). 
the High Court specifically found that, in England, Champagne had not met the fate of other wines such as Burgundy, Sherry, Hock, whose names have lost their initial capital letters and have become generic for a class of wines. ${ }^{\mathbf{1 3 7}}$ Nevertheless, a word may be descriptive without having become generic. In a practical sense, there is hardly any other appellation to give perelada but "champagne" if the seller is to succeed in communicating to non- $U$ buyers what is in his bottles; we question whether "sparkling white wine" would convey much meaning to the brides' mothers whom Costa Brava was attempting to reach. Denying the perelada seller the privilege of describing his wares in terms of "champagne" effectively prevents his competition. Finally, as for the mother's passing perelada off as champagne to her guests, considerations that we have discussed in connection with the Atmos Clock case would suggest that she should be allowed to do her worst.

Perhaps something substantial is lost by not balancing the conflicting public interests with one another to maximize the total public good-particularly in cases like the Camel Hair case, where descriptiveness is slight. But as a concession to the shortness of life and the institutional capacity or incapacity of courts, we believe the solution of the Restatement and the American decisions it follows is to be preferred to that of the English courts. There is another reason for this view, less technical and more conjectural, but probably given considerable weight in the American decisions. This is the public injury doctrine that unfair competition law exists to protect the public qua consumer. ${ }^{138}$ When this is coupled with the premise that it is inherently more probable that the public harm from weakened competition will exceed the public harm from deception ${ }^{139}$ (perhaps a con-

137 While the court in the Spanish Champagne case found that "champagne" was not generic for sparkling white wine in England, [1961] 1 Weekly I.R. at 286, no finding of secondary meaning in our sense of the term was made.

138 See Smith, Wealth of Natrons 625 (Modern Library ed. 1937): "Consumption is the sole end and purpose of all production; and the interest of the producer ought to be attended to, only so far as it may be necessary for promoting that of the consumer." Judge Frank has characterized as fundamental to laissez-faire jurisprudence the assumption that "where the economic interest of consumers conflicted with the economic interest of the [commercial] competitor, only the consumer interest was judicially considered." Standard Brands, Inc. v. Smidler, 151 F.2d 34, 40 (2d Cir. 1945) (concurring opinion). See also Societe Comptoir de L'Industrie Cotonniere v. Alexander's Dep't Stores, Inc., 299 F.2d 33, 37 (2d Cir. 1962) ; American Safety Table Co. v. Schreiber, 269 F.2d 255, 271 (2d Cir.), cert. denied, 361 U.S. 915 (1959), discussed in note 158 infra.

139 See text accompanying note 107 supra. For a carefully articulated, uncompromising exposition of this view, see Application of Deister Concentration Co., 289 F.2d 496, 503-04 (C.C.P.A. 1961). Although the point in issue was whether a functional mark (mark consisting of functional configuration of surface of ore processing table) could be registered under $\$ 2(f)$ of the Trademark Act of 1946,60 Stat. 428,15 U.S.C. $\S 1052(\mathrm{f})$ (1958) (marks distinctive of applicant's goods), the court essayed an extended analysis of the status of functional configurations of goods in trademark 
jectural premise, to be sure), it follows that the newcomer should be permitted to imitate the functional or descriptive feature of the innovator's product even when fair warning is not feasible. Moreover, for whatever it is worth, the previously discussed policy of reluctance to permit any state action except upon a clear showing of public benefit weighs against court intervention in such cases.

The entire foregoing discussion may be summarized with respect to the schematization of the cases presented in Table $I$. Thus, with respect to categories 5-8, the copying is lawful, whereas, with respect to category 4 , it is not. It is only in the area represented by categories 1-3 that a further factor-adequate warning-must be applied before the lawfulness of the copying can be determined. This may be presented in true-false tabular form, based on whether adequate warning is:

\section{TABLE II}

\begin{tabular}{|c||c|c|c|}
\multicolumn{1}{c|}{ Feasible } & Given & Copying Lawful \\
\hline (A) & $\mathrm{T}$ & $\mathrm{T}$ & $\mathrm{T}$ \\
(B) & $\mathrm{T}$ & $\mathrm{F}$ & $\mathrm{F}$ \\
(C) & $\mathrm{F}$ & $\mathrm{F}$ & $\mathrm{T}$ \\
\hline
\end{tabular}

III. "Misappropriation" Versus "Public InJury"

The misappropriation doctrine is applied at times without explicit recognition, as in the Notre Dame and Atmos Clock cases. Again, "misappropriation" may be relied upon, as in the Mustard Seed case, without extended doctrinal exposition. In these circumstances, "misappropriation" has not been given harsh treatment in the courts. But when the courts have examined the doctrine with more care, they frequently have refused to give it any more than a nominal scope. The reception of the New York statute in the federal courts since the Mustard Seed case illustrates these conflicts and highlights, we believe, the essential inadequacies of the whole misappropriation doctrine.

and unfair competition cases. The teaching of the cases which is distilled by the court is that, despite loose language in many opinions that functional configurations are incapable of indicating source of origin, such features clearly can and do signify source, but "there is an overriding public policy of preventing their monopolization, of preserving the public right to copy." 289 F.2d at 504. Compare Restarement, Torts $\$ 721$, comment $a$ (1938). Hence, registration of the mark, with consequent legal recognition of the exclusive right in it of the applicant, was denied. In so holding, the court recognized the risk of public deception entailed, but concluded that, on balance, "a certain amount of purchaser confusion may even be tolerated in order to give the public the advantages of free competition." 289 F.2d at 504. 
Section 368-d of the New York General Business Law establishes, as a ground for injunctive relief, "likelihood of injury to business reputation . . . in cases of . . . unfair competition, notwithstanding the absence of . . . confusion as to the source of goods . . . ."140 As worded, the statute does not forbid all copying of goods. It is improbable that this would even have been intended, ${ }^{141}$ for the consequent encroachment on the common right to compete would be unparalleled. ${ }^{142}$ In any event, the courts have declined so to construe the statute, reading the two qualifying phrases of the section ("likelihood of injury" and "case of unfair competition") as limitations on its scope.

Thus, in Joshua Meier Co. v. Albany Novelty Mfg. Co., ${ }^{143}$ the court of appeals denied a preliminary injunction against copying public domain ideas (descriptive marks and names long used for goods by the industry), because there could be no "injury" to plaintiff as a consequence of such copying. The reasoning of the court appears to be that the only "injury" to the innovator from copying public domain matter is the injury occasioned by the existence of free competition, to which the "innovator" (that is, he who first appropriates) will not be heard to object when he raises the cry of "misappropriation." 144 This view was expressed even more emphatically in Vacheron \& Constantin-

140 The section further provides for injunctions against "dilution of the distinctive quality of a trade name or trade-mark . . . in case of trade-mark infringement or unfair competition," despite absence of source confusion. The Massachusetts statute, MASS. ANN. LAws ch. 110, \&7A (1954), has substantially the same wording as the New York act GA. CODE ANN. \$ 106-115 (1956) and ILL. ANN. STAT. ch. 140, § 22 (Smith-Hurd Supp. 1961) are also "antidilution" statutes, although they are worded differently.

141 Cf. Schwegmann Bros. v. Calvert Distillers Corp., 341 U.S. 384, 389-90 (1951) ; Gibbons v. Ogden, 22 U.S. (9 Wheat.) 1 (1824); Capitol Records, Inc. v. Mercury Records Corp., 221 F.2d 657, 667 (2d Cir. 1955) (dissenting opinion of L. Hand, J.). These cases appear to suggest that the New York law would burden commerce and confict with the federal patent and copyright laws if its intent were to foreclose all copying. See also Kessler \& Stern, supra note 109, at $100 \mathrm{n} .455$ (final query on conflict with Sherman Act). See generally KapLAN \& Brown, CASES oN Copyright, UNFAIR Competition, and Other Topics 613-14 (2d ed. 1960).

142 Compare Case of the Clothworkers of Ipswich, Godbolt 252, 78 Eng. Rep. 147 (K.B. 1653) ; Case of the Tailors of Ipswich, 11 Coke 53a, 77 Eng. Rep. 1218 (K.B. 1614); The Case of Monopolies, 11 Coke 84a, 77 Eng. Rep. 1260 (K.B. 1602); The Schoolmaster Case, Y.B. Hil. 4 Hen. 11, f. 47, pl. 21 (1409). We suggest here, in a very tentative way, a substantive due process consideration not for purposes of making an unconstitutionality argument, as such, but for purposes of negativing an interpretation of the legislative "intent" that would require a reading of questionable constitutionality. Cf. Crowell v. Benson, 285 U.S. 22, 62 (1932).

143236 F.2d 144 (2d Cir. 1956). Accord, Guardian Life Ins. Co. of America v. Guardian Nat'l Life Ins. Co., 184 F. Supp 851, 855 (E.D. La. 1960).

144 This is, of course, a dannum absque injuria argument. See 3 RESTATEMENT, TorTs 537 (1938); cf. Tennessee Elec. Power Co. v. TVA, 306 U.S. 118, 140 (1939); Alabama Power Co. v. Ickes, 302 U.S. 464, 479-85 (1938); Stratton v. Conway, 201 Tenn. 582, 301 S.W.2d 332 (1957) ("blockbusting" held dammum absque injuria on policy grounds). It should also be noted that courts usually condition grant of injunctive relief on a showing of irreparable injurry. Beacon Theaters, Inc. V. Westover, 359 U.S. 500, 506-07 (1959); State Corp. Comm'n v. Wichita Gas Co., 290 U.S. 561, 568 (1934). 
Le Coultre Watches, Inc. v. Benrus Watch Co., ${ }^{145}$ in which the innovator was denied relief against the copying of his watch design on the ground that there was no likelihood of injury to business reputation, within the meaning of section 368-d, absent secondary meaning. Taking a slightly different approach, in Kitchens of Sara Lee. Inc. $v$. Nifty Foods Corp., ${ }^{146}$ the court of appeals held that unless the product had acquired a secondary meaning as originating with plaintiff there could be no "case of unfair competition," to which class of case the statute is in terms restricted.

These narrow constructions are not dictated merely by the courts' fussiness over the semantic contradiction between the statutory phrases "likelihood of injury" in "cases of unfair competition" and "absence of confusion as to source." These courts are hardly unaware that damnum absque injuria, like "proximate cause," is a policy notion, ${ }^{\mathbf{1 4 7}}$ or that "cases of unfair competition" can be redefined by the legislature in a sense different from that of the common law, at least in principle. The statute has invited restrictive construction by neglecting to define effectively the scope of injury-which is to say that it fails to redefine the common-law boundaries of the public domain. No definite legislative standard is established for distinguishing between permissible and impermissible copying. ${ }^{148}$ When the courts, particularly the federal appellate courts, so construe section $368-\mathrm{d}$ as to deny it any real scope of application, they would appear to be compelled to do so for want of a legislative standard, if they are to keep the statute from making perilous and unlimited inroads on the public domain. ${ }^{149}$ This is, we believe, the reason for the substantial failure of the New York statute to reshape the case law.

145155 F. Supp. 932, 936 (S.D.N.Y. 1957), modified on other grounds, 260 F.2d 637 (2d Cir. 1958). By the same token, the argument can be made that absent secondary meaning there can be no "dilution of the distinctive quality of a trade name or trade-mark," see note 139 supra, for there is nothing to dilute. One can water down milk, but one cannot water down water. Compare Food Fair Stores, Inc. v. Food Fair, Inc., 83 F. Supp. 445, 451 (D. Mass. 1948) and Skil Corp. v. Barnet, 337 Mass. 485, 490, 150 N.E.2d 551, 554 (1958), with Food Fair Stores, Inc. v. Food Fair, Inc., 177 F.2d 177, 185 (1st Cir. 1949) (affirming district court decree sipra).

146266 F.2d 541, 545-46 (2d Cir. 1959). See also Blisscraft of Hollywood v. United Plastic Co., 189 F. Supp. 333, 338 (S.D.N.Y. 1960), aff'd (on the basis of the "indeterminate general law"), 294 F.2d 694, 697-98 (2d Cir. 1961) (also relying on Pepto$B$ ismol case). Among other cases which attempted to distinguish or restrict $\$ 368$ are Societe Comptoir de L'Industrie Contonniere v. Alexander's Dep't Stores, Inc, 299 F.2d 33, 36 (2d Cir. 1962) ; Norwich Pharmacal Co. v. Sterling Drug, Inc., 271 F.2d 569 (2d Cir. 1959), cert. denied, 362 U.S. 919 (1960) (Pepto-Bismol case); Dawn Donut Co. v. Hart's Food Stores, Inc., 267 F.2d 358, 366 (2d Cir. 1959); Barton Candy Corp. v. Tell Chocolate Novelty Corp., 178 F. Supp. 577 (E.D.N.Y. 1959), but they contribute less to the advancement of the analysis.

147 See note 60 supra.

148 See 69 Harv. L. Rev. 392, 393 (1955).

149 Compare the cases denying enforcement to incomprehensibly vague statutes without relying upon particular constitutional provisions, e.g., United States v. Cardiff, 344 U.S. 174 (1952); United States v. Evans, 333 U.S. 483 (1948). See also Aigler, Legislation in Vague or General Terms, 21 MicH. L. Rev. 831 (1923); Note, 109 U. PA. L. REv. 67 n.2 (1960). 
Nor has any other legislature (or court) succeeded in formulating a rationale for misappropriation which more adequately delineates the scope of the interest to be protected. ${ }^{150}$ This absence of definition of the altered boundary of the public domain does not result, we believe, from lack of ingenuity in draftsmanship or even from mere unwillingness of misappropriation doctrine supporters to admit that they are proponents of an enclosure movement. It is submitted that the defect is deeper: The inability to define misappropriation with any precision is the necessary consequence of the inherent vagueness of the subject matter.

Proponents of the misappropriation theory have defended its vagueness on the ground that it permits flexible adjustment to meet a variety of fact situations as they arise. ${ }^{151}$ This is, we submit, to take refuge in a case-by-case analysis that amounts in the end to no analysis at all. ${ }^{152}$ To the extent that law should serve a predictive function, a law of unfair competition based on case-by-case determination of whether there has been misappropriation fails abysmally in its task. The effect of this juridical risk on the small businessman who cannot afford to make blind guesses which may cause the destruction of his business is manifest; the result of the misappropriation doctrine may well be the discouragement of even such copying as might ultimately be held legitimate under the most ambitious misappropriation theory. ${ }^{163}$ Moreover, the "convenient vagueness" 154 of the misappropriation doctrine is objectionable on more general grounds. Basically, what defenders of the vagueness theory of unfair competition law contemplate is a carte blanche to the courts to write their own code of business morality. ${ }^{155}$ But as Professor Kessler has observed in another context: "[I]f carried to its logical conclusion [this] may mean an enormous increase in control over private volition which may in turn re-

150 See, e.g., statutes cited note 140 supra. See also H.R. 4590, 87th Cong., 1st Sess. (1961).

151 E.g., Sell, The Doctrine of Misappropriation in Unfair Competition, 11 VAND. L. REv. 483, 496-98 (1958) ; 107 CoNG. REC. 2439 (1961) (explanatory statement on H.R. 4590).

152 See note 109 supra and accompanying text.

153 The devastating uncertainty and disastrous risks to small businessmen which are created by nebulous and permissive judicial standards for determining what copying is permissible or impermissible are discussed in the concurring opinion of Black, J., in Aro Mfg. Co. v. Convertible Top Replacement Co., 365 U.S. 336, 357-59 (1961).

154 See Pillsbury Mills, Inc., 50 F.T.C. 555, 569 (1953) ("far from specific standards" of Clayton Act regarded as desirable and consistent with "convenient vagueness" needed in antitrust proceedings).

155 See H.R. 4590, 87th Cong., 1st Sess. \$2(c) (1961) ("violates reasonable standards of commercial ethics"), as explained in 107 CoNG. REc. 2439 (1961). See also Lunsford, Unfair Competition: Uniform State Act Needed, 44 VA. L. REv. 583, 600-01 (1958) ("contrary to commercial good faith or to the normal and honorable development" of industrial, commercial, agricultural, or other business activities). 
sult in the imposition of a tyrannical stranglehold on the behavior patterns of the community." 156

The further deficiency of the misappropriation doctrine, apart from the necessary consequences of its ill-defined compass, is that to the extent it articulates any policy, it dictates the sacrifice of public interests to protect the assertion of private interests. ${ }^{157}$ Because it is neither related to nor restricted to the aspect of the public interest safeguarded by the traditional rule, that of preventing consumer deception, the misappropriation doctrine endangers the public interest in free competition without compensating public benefits. ${ }^{158}$ To be sure, some conceive the function of an unfair competition law based on misappropriation to be complementarily related to the public interest, in that it will provide merely "a reasonable supplement" to the publicinterest-oriented Federal Trade Commission Act in order to protect private interests. ${ }^{159}$ But such a "supplemental" approach overlooks the fact that the public interest is always involved in the regulation of competition: to "supplement" is pro tanto to "supplant." 160 Whenever copying is prohibited, the scope of competition in the production and marketing of the copied product is likewise reduced, thereby compromising to some degree the basic free enterprise premise "that the unrestrained interaction of competitive forces will yield the best allocation of our economic resources, the lowest prices, the highest quality and the greatest material progress." 181

To be sure, all this may occasionally conflict with the basic proposition that people ought not to be deceived. But when the public interest in competition is unopposed by another public interest, we submit that it ought not to be compromised. Whatever merits the mis-

156 Kessler, supra note 112, at 167 (discussion of good faith). See also Rushmore v. Manhattan Screw \& Stamping Works, 163 Fed. 939, 942 (2d Cir. 1908) (dictum: if the law of unfair competition be pushed much further, result may be intolerable state of judicial paternalism); text preceding note 97 supra.

157 See Norwich Pharmacal Co. v. Sterling Drug, Inc., 271 F.2d 569, 570-71 (2d Cir. 1959), cert. denied, 362 U.S. 919 (1960) (Moore, J.: "Distaste for sharp or unethical business practices has often caused the courts to lose sight of the fundamental consideration in the law of unfair competition-protection of the public."). See also note 138 supra.

$158 \mathrm{An}$ excellent articulation of this view, which did not, however, prevent the grant of sweeping and perhaps unjustifiable relief against the copying of functional features in the public domain, when a requirement of warning might have sufficed to protect the public against deception, is found in American Safety Table Co. v. Schreiber, 269 F.2d 255, 271-72 (2d Cir.), cert. denied, 361 U.S. 915 (1959).

159 See Note, 70 Yale L.J. 406, 438 (1961).

160 Compare McGuire Act $\$ 2$ (a) (2)-(4), 66 Stat. 632 (1952), 15 U.S.C. \$ 45 (a) (2) - (4) (1958); Robinson-Patman Act $\$ \$ 2,2 \mathrm{a}, 49$ Stat. 1528 (1936), 15 U.S.C. $\S \S 13,13 \mathrm{a}(1958)$.

161 See Northern Pac. Ry. v. United States, 356 U.S. 1, 4 (1958). This may be restated more colorfully in the language then Assistant Attorney General Thurman Arnold used in the oral argument of United States v. Socony-Vacuum Oil Co., 310 U.S. 150 (1940) - "Thank God for the chiseler." 
appropriation doctrine may have in the neutral case (category 8 supra) or where fair warning is not feasible, and we doubt that it has any there, certainly it is without merit when there is functionality or descriptiveness or when there is no consumer deception (because there is no secondary meaning or because there is fair warning).

The conclusion we draw is that preservation of the proper rule of unfair competition law depends on the retention of likelihood of consumer deception, which means retention of secondary meaning, as an indispensable condition to the maintenance of the innovator's suit. Abandonment of the "public injury" requirement in these private trade regulation suits would most unfortunately restrain those competitive forces on whose action our economy is based, and would impair the personal freedom from state action to which our social order is dedicated. 